\title{
Attacking Brandenburg with History: Does the Long-Term Harm of Biased Speech Justify a Criminal Statute Suppressing It?
}

Anuj C. Desai

University of Wisconsin Law School

Follow this and additional works at: https://www.repository.law.indiana.edu/fclj

Part of the Civil Rights and Discrimination Commons, Communications Law Commons, Constitutional Law Commons, and the First Amendment Commons

\section{Recommended Citation}

Desai, Anuj C. (2003) "Attacking Brandenburg with History: Does the Long-Term Harm of Biased Speech Justify a Criminal Statute Suppressing It?," Federal Communications Law Journal: Vol. 55 : Iss. 2 , Article 8.

Available at: https://www.repository.law.indiana.edu/fclj/vol55/iss2/8

This Book Review is brought to you for free and open access by the Law School Journals at Digital Repository @ Maurer Law. It has been accepted for inclusion in Federal Communications Law Journal by an authorized editor of Digital Repository @ Maurer Law. For more information, please contact rvaughan@indiana.edu.

\section{$\Psi$}

JEROME HALL LAW LIBRARY

INDIANA UNIVERSITY

Maurer School of Law
Bloomington 


\section{BOOK REVIEW}

\section{Attacking Brandenburg with History: Does the Long-Term Harm of Biased Speech Justify a Criminal Statute Suppressing It?}

Destructive Messages: How Hate Speech Paves the Way for Harmful Social Movements, Alexander Tsesis, New York: New York University Press, 2002, 246 pages.

Anuj C. Desai*

I. INTRODUCTION 354

II. Definitional Problems With the Phrase "HATE SPEECH” .. 358

III. HISTORY, CAUSATION, AND BIASED SPEECH …............................ 362

A. Historiographical Debates About the Causes of the Holocaust and American Slavery ......................................... 362

B. Causation Theory and the Claim that Biased Speech Causes Long-Term Harm ..................................................... 367

C. The Need for Comparative Analysis ...................................... 373

IV. CRIMINal LaW as a SOlUtion to THE LONG-Term HaRm CAUSED BY BIASED SPEECH ..................................................... 379

A. Brandenburg, Biased Speech, and Government Power ........ 381

B. The Need for Precision in Drafting a Criminal Prohibition on Biased Speech ................................................................... 390

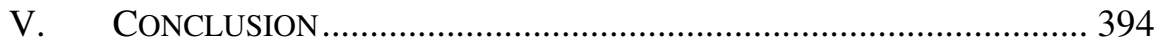

Copyright (C) 2003 Anuj C. Desai.

* Assistant Professor of Law, University of Wisconsin Law School. The following individuals read earlier drafts of this Review and improved it immensely: Nina Chang, Nancy Amoury Combs, Howie Erlanger, Jane Larson, Greg Magarian, Sarah Maguire, Robert Post, Richard Ross, and Jane Schacter. Sarah also provided superb research assistance. In addition, I had helpful conversations about specific aspects of the argument with KT Albiston, Val Jenness, Len Kaplan, John Schmitt, Michael Smith, and Bernie Trujillo. Mike Morgalla and Cheryl O'Connor were indispensable in tracking down many of the obscure sources that those of you who read footnotes will find littered throughout the piece. All the usual disclaimers apply. 


\section{INTRODUCTION}

The relationship between speech and action is one of the most complex in the law of communications. Assumptions about the relationship pervade any number of First Amendment doctrines, from the secondary effects doctrine, ${ }^{1}$ to the fighting words doctrine, ${ }^{2}$ to the "true threat" doctrine, ${ }^{3}$ helping to explain why many speech-related crimes (for example, conspiracy, threats, fraud, and contempt of court) are not ordinarily thought even to raise First Amendment issues. ${ }^{4}$

In his new book, Destructive Messages: How Hate Speech Paves the Way for Harmful Social Movements, ${ }^{5}$ Alexander Tsesis sets forth a thesis about the relationship between what he refers to as "hate speech", and action that follows from it. His broad claim about the relationship is simple and straightforward: When systematically developed over long periods of time, "hate speech" lays the foundation for harmful social movements that ultimately result in the oppression and persecution of "outgroups." From

1. City of Renton v. Playtime Theatres, Inc., 475 U.S. 41 (1986) (holding that zoning ordinances designed to combat the undesirable "secondary effects" of adult-entertainment establishments are content-neutral regulations subject only to intermediate scrutiny and survive First Amendment scrutiny).

2. Chaplinsky v. New Hampshire, 315 U.S. 568 (1942) (holding that so-called "fighting words" fall outside the ambit of constitutionally protected speech); see also R.A.V. v. St. Paul, 505 U.S. 377 (1992) (invalidating a bias-motivated crime ordinance as content based notwithstanding the fact that the ordinance was limited to "fighting words").

3. Watts v. United States, 394 U.S. 705, 707 (1969) (per curiam) (stating that a law that criminalized threats against the president was "constitutional on its face"). Compare also Black v. Commonwealth, 553 S.E.2d 738, 748, 751 (Va. 2001) (Hassell, J., dissenting), cert. granted, 122 S. Ct. 2288 (2002), with id. at 747 (Kinser, J., concurring) (arguing that the same statute is unconstitutional because "there is a difference between threat and intimidation and ... intimidation may occur without threats" (citation and internal quotation marks omitted)).

4. I say "ordinarily" because it is of course the exceptions that prove the rule. See, e.g., Cohen v. California, 403 U.S. 15 (1971) (reversing a so-called "breach of the peace" conviction against a defendant who wore a jacket with the words "Fuck the Draft"). The literature on this question broadly speaking is extensive. See generally KENT GREENAWALT, SPEECH, CRIME, AND THE USES OF LANGUAGE (1989).

5. Alexander Tsesis, Destructive Messages: How Hate Speech Paves the Way FOR HARMFUl SOCIAL MOVEMENTS (2002) [hereinafter TSESIS]. The book is an expansion of one of the author's law review articles: Alexander Tsesis, The Empirical Shortcomings of First Amendment Jurisprudence: A Historical Perspective on the Power of Hate Speech, 40 Santa Clara L. Rev. 729 (2000).

6. I will use the phrase "hate speech" in the introduction, as it is the one he uses. I will, however, include quotation marks around the phrase because, as I describe in greater detail below, Tsesis himself uses the phrase "hate speech" in different ways depending on the context. In some places in the book, his notion of "hate speech" includes Chaucer, Shakespeare, and Dickens. TSESIS, supra note 5, at 111. However, his explicit definition of it is somewhat different. $I d$. at 207. This ambiguity is a problem for a number of reasons that I discuss in detail below in Part II. 
this premise, he argues that United States courts should abandon the rule that advocacy or incitement must be likely to result in imminent harm before it can be constitutionally proscribed, ${ }^{7}$ and that legislatures should criminalize "hate speech." He then concludes the book with a proposed statute to do just that.

The book is composed of three parts. In the first part, Tsesis coins the phrase "misethnicity" to describe "hatred toward groups because of their racial, historic, cultural, or linguistic characteristics." ${ }^{8}$ He then devotes the bulk of the first part of the book to three historical case studies: the Holocaust, slavery in the United States, and the U.S. nineteenth-century policy of Native American removal. He argues that, in each instance, "hate speech" laid the groundwork for the oppression that followed. After these historical examples, he then discusses contemporary society in two countries, Mauritania and the United States, and argues that "hate speech" continues to cause trouble in both places.

In the second part of the book, Tsesis argues that, because of the social psychology of scapegoating, "hate speech" can draw upon herd mentality in a way that leads to persecution of "outgroups." Like the historical examples he gives in the first part of the book, this part is meant to show that "hate speech" leads to, or in some sense causes, ${ }^{9}$ harm beyond those instances when there is an "imminent" threat of harm.

The final part of the book is entitled "Legal Response to Hate Speech." In it, Tsesis relies on his historical claims to critique current Supreme Court doctrine:

Current Supreme Court hate speech doctrine fails to take into account the long-term social dangers of hate propaganda. The need for reconsidering that doctrine emerges after our sociohistorical survey of how, at various times, utterances and ideology gradually raised the pitch of hatred until they instigated grand-scale tragedies such as the Holocaust, Native American dislocation, and black slavery.

He then explains that much of the rest of the world criminalizes "hate speech" in some form and concludes that the United States should do the same. At the end of the book, Tsesis proposes a model statute to criminalize "hate speech."

At one level, the book's thesis is simply one in a long line of arguments about the need to regulate racist speech. ${ }^{11}$ Indeed, at times

7. See Brandenburg v. Ohio, 395 U.S. 444 (1969).

8. TSESIS, supra note 5, at 81 . I will use the term, as it covers ideologies that do not fit literally into the term "racism."

9. I discuss Tsesis's claim of causation in great detail below. See Part III.B.

10. TSESIS, supra note 5, at 130 .

11. The American legal literature includes a number of different arguments in favor of 
Tsesis relies upon and restates many of these arguments. ${ }^{12}$ Yet on another level, it is fundamentally different from much American literature on "hate speech" because Tsesis draws on such a broad historical swath, and because he contends that the United States should regulate "hate speech" due to a causal link between that speech and oppression of such magnitude as the Holocaust and slavery. Moreover, it is fundamentally different because Tsesis focuses on the ideology of racial inferiority and not where most proponents of regulating "hate speech" in the past have set their sights - epithets, or what one could term "verbal assaults." 13

To American lawyers steeped in the modern First Amendment, Tsesis's thesis is bold, indeed radical. It is, however, little more than an importation of the theoretical underpinnings of an approach to regulating racist ideologies that much of the rest of the world-Europe, in particular-has relied upon, ${ }^{14}$ and one that Americans will increasingly have to grapple with as changes in communication technologies impose pressure to harmonize laws regulating information and expression. ${ }^{15}$

regulating racist speech, the most prominent of which are: 1) Racist speech is group defamation. See Mari J. Matsuda, Public Response to Racist Speech: Considering the Victim's Story, 87 Mich. L. REv. 2320, 2358 (1989) (drawing on group libel and Beauharnais). 2) Racist speech causes significant emotional injury to specific individuals. Richard Delgado, Words That Wound: A Tort Action for Racial Insults, Epithets, and NameCalling, 17 HARV. C.R.-C.L. L. REV. 133, 137 (1982) (analogizing racist speech to dignitary torts, such as defamation and intentional infliction of emotional distress). 3) Racist speech silences those on its receiving end and thus undermines the marketplace of ideas. Charles R. Lawrence III, If He Hollers Let Him Go: Regulating Racist Speech on Campus, 1990 DUKE L.J. 431, 471-72 (arguing that racist speech "decreases the total amount of speech that reaches the market"). 4) Basic principles of equality require such regulation, independent of any concrete harms. R. George Wright, Racist Speech and the First Amendment, 9 Miss. C. L. REV. 1, 14-22 (1988) (referring to the "deontic" or intrinsic harm of racist speech); David Kretzmer, Freedom of Speech and Racism, 8 CARDOZO L. REV. 445, 456 (1987) (noting argument that a "society committed to ideals of social and political ... equality ... must issue unequivocal expressions of solidarity with vulnerable minority groups"). See generally Robert C. Post, Racist Speech, Democracy, and the First Amendment, 32 WM. \& MARY L. Rev. 267, 271-78 (1991); JAMEs Weinstein, Hate Speech, Pornography, AND the RADICAL ATTACK ON FREE SPEECH DOCTRINE 127-35 (1999).

12. See, e.g., TSESIS, supra note 5, at 100 ("Ethnic and racial insults are defamatory statements against individuals based on their membership in identifiable groups.").

13. See, e.g., Matsuda, supra note 11, at 2332.

14. International Covenant on Civil and Political Rights, Dec. 19, 1996, art. 20(2), 999 U.N.T.S. 171, 178 (entered into force Mar. 23, 1976); International Convention on the Elimination of All Forms of Racial Discrimination, Mar. 7, 1966, art. 4, 660 U.N.T.S. 211, 218-20 (entered into force Jan. 4, 1969). See Matsuda, supra note 11, at 2341-48.

15. For Americans, one recent example of this harmonization is the promulgation of the anti-circumvention and anti-trafficking provisions of the Digital Millennium Copyright Act in 1998. 17 U.S.C. $\S 1201$ (2000). Those provisions began as a domestic initiative in the United States. See Working Group on Intellectual Prop. Rights, U.S. DeP'T of COMMERCE, InTELlectual PROPERTy AND the NATIONAL INFORMATION INFRASTRUCTURE 
Moreover, in a broader historical sense, it is Brandenburg, ${ }^{16}$ not Tsesis's argument, that is revolutionary; the notion that speech can cause long-term harm and that it should be suppressed to avoid those harms has been around at least since Plato argued that the poets should be banned from the Republic because they corrupted the youth. ${ }^{17}$

While Tsesis has raised some interesting issues for Americans to think about and has done a service by asking Americans to better understand why much of the rest of the world regulates biased ideologies, his argument ultimately fails to provide a sufficiently convincing reason for either abandoning Brandenburg or adopting his proposed statute.

In Part II, I discuss the different ways Tsesis uses the phrase "hate speech" and how this variety of definitions undermines the connection between his proposed statute and the long-term harms he describes. In Part III, I discuss the historical claims Tsesis makes, claims that form the premise of his argument. I argue that he has failed to engage major historiographical debates and that readers of his book should thus be skeptical of his claims. In Part III, I also discuss Tsesis's methodological approach and suggest that a comparative analysis might more fruitfully uncover the role that "hate speech" plays in the concrete harms he describes. In Part IV, I turn to Tsesis's proposal. In Part IV.A, I argue that because he has misunderstood one of the underlying bases of the imminent harm requirement in Brandenburg, he is unlikely to convince American courts to abandon the doctrine. Finally, in Part IV.B, I look closely at the language of the statute that Tsesis proposes, arguing that the proposed statute, as drafted, would criminalize core political speech, a problem that needs to be corrected even if one were to accept both his historical premise

(1995), available at http://www.uspto.gov/web/offices/com/doc/ipnii/. They then eventually became domestic law only after they were written into the WIPO Copyright Treaties. See Digital Millennium Copyright Act, Pub. L. No. 105-304, 112 Stat. 2860, tit. I (1998). Much of what has been driving this move toward harmonization is the assumption that the Internet is enabling what Michael Froomkin refers to as "regulatory arbitrage"- the ability "to choose to evade disliked domestic regulations by communicating/transacting under regulatory regimes with different rules." A. Michael Froomkin, The Internet as a Source of Regulatory Arbitrage, in BORDERS IN CYBERSPACE: INFORMATION POLICY AND THE GLOBAL INFORMATION INFRASTRUCTURE 129, 142 (Brian Kahin \& Charles Nesson eds., 1997).

16. In Brandenburg v. Ohio, the Supreme Court held that advocacy or incitement must be likely to result in imminent harm before it may be constitutionally proscribed. 395 U.S. 444 (1969).

17. See Plato, The Republic Book 10, Ch. I (Paul Shorey trans., Harvard University Press 1956) (poetry "seems to be a corruption of the mind of all listeners who do not possess as an antidote a knowledge of its real nature"); $i d$. at Ch. XVI. I am indebted to my colleague Len Kaplan for this point. 
and the general idea that a criminal prohibition on "hate speech" is an appropriate response to the historical atrocities he describes in the first part of the book.

\section{DEFINITIONAL PROBLEMS WITH THE PHRASE "HATE SPEECH"}

Tsesis uses the phrase "hate speech" in a variety of different ways. His stated definition differs from his statutory definition, and more importantly, these two explicit definitions differ from the implied definition he uses to set forth the historical and psychological premises of the book. This fact fundamentally undermines his thesis.

Let us look first at his stated definition. At the beginning of the book, Tsesis equates "hate speech" with three other phrases: "hate propaganda," "destructive messages," and "biased speech." He defines "hate speech" as "antisocial oratory that is intended to incite persecution against people because of their race, color, religion, ethnic group, or nationality, and has a substantial likelihood of causing such harm." $" 18$ He then goes on to say that "[t]his definition does not include verbal attacks against individuals who incidentally happen to be members of an outgroup." no requirement of hatred in his definition of "hate speech," and he specifically excludes "verbal attacks" (that is, epithets), which is likely what the phrase first evokes to most Americans and is certainly what most, if not all, other American scholars refer to when they use the phrase "hate speech." ${ }^{20}$ This definition allows Tsesis to use the phrase "hate speech" to advocate for the suppression of what is in effect expressions of racist ideology. ${ }^{21}$

At the end of the book, Tsesis proposes a statute for criminalizing "hate speech" based on his earlier definition. At this point, he alters the earlier definition in two ways. First, he creates certain limits on his original definition by including an "intent to promote destructive behavior" requirement and an affirmative defense for "statement $[\mathrm{s}]$... uttered as an

18. TSESIS, supra note 5, at 211.

19. Id. (emphasis added).

20. See Matsuda, supra note 11, at 2354-56; see also Delgado, supra note 11, at 135; Robert J. Boeckmann \& Carolyn Turpin-Petrosino, Understanding the Harm of Hate Crime, 58 J. Soc. Issues 207, 209 (2002) ("Hate speech is any form of expression directed at objects of prejudice that perpetrators use to wound and denigrate its recipients." (emphasis added)) .

21. Tsesis's definition lends a certain irony to Henry Louis Gates's description of the phrase "hate speech" as "ideology in spansule form." Henry Louis Gates, Jr., War of Words: Critical Race Theory and the First Amendment, in Speaking of RaCE, Speaking Of Sex: Hate SPEeCh, Civil Rights, AND Civil LiberTies 17, 17 (Henry Louis Gates, Jr. et al. eds., 1994). 
expression of opinion on a neutral scientific, academic, or religious subject and/or ... statement[s] ... made to eliminate the incidence of hatred toward a historically persecuted group." 22 Second, he broadens the original definition: While his original definition is limited to "antisocial oratory that is intended to incite persecution," 23 his criminal definition covers "[a]nyone inciting others to discriminate, persecute, oppress, or commit any similar acts." ${ }^{24}$ I address some of the problems with the language of his proposed criminal statute in Part IV.B. For now, the differences between these two definitions are immaterial. What I want to focus on is the inconsistency between these two explicit definitions and the implied one he uses in arguing that first, "hate speech" led to the Holocaust, American slavery, and the U.S. policy of expelling indigenous Americans from their land; and second, through the social psychology of scapegoating, "hate speech" "elicits emotional and motivational responses, thereby easing guilt about groupwide mistreatment and injustice." 25

Consider some of the examples of racist ideology and propaganda that Tsesis says should be viewed as leading to the historical calamities he describes in the first part of the book. As part of the background that led to the Holocaust, Tsesis cites a German journalist who, in the 1870s, stated, "Today the social question is essentially the Jewish question. All other explanations of our economic troubles are fraudulent cover-ups." ${ }^{26}$ Or, consider his reliance on Thomas Jefferson's statement that blacks were "inferior to whites in the endowments both off [sic] body and mind.... This unfortunate difference of color, and perhaps of faculty is a powerful obstacle to the emancipation of these people." 27 Another example is Tsesis's citation to President Andrew Jackson's comments supporting the U.S. policy of expelling indigenous Americans from their land in the nineteenth century. Jackson relied on the imagery of natives as "hunters and gatherers," asking rhetorically, "[I]s it to be supposed that the wandering savage has a stronger attachment to his home than the settled, civilized Christian?"28

These are just a few of the utterances that, according to Tsesis, led to the Holocaust, American slavery, and expulsion of indigenous Americans from their land. He is undoubtedly correct to characterize these claims as

22. TSESIS, supra note 5, at 207-08.

23. Id. at 211 (emphasis added).

24. Id. at 207 (emphasis added).

25. Id. at 5 .

26. Id. at 14 (quoting Otto von Glogau).

27. Id. at 35 (citation omitted).

28. $I d$. at 60 . 
misethnic ideology or biased speech. The question, though, is whether they constitute "hate speech" that he seeks to criminalize. In particular, would these statements satisfy his criminal definition? ${ }^{29}$ Would the person who made these statements be entitled to the benefit of his affirmative defense for statements "uttered as an expression of opinion on a neutral scientific, academic, or religious subject"? ${ }^{30}$ Were these statements "intended to incite persecution" or "intended to promote destructive behavior"? ${ }^{31}$ At no point does Tsesis explicitly address the question. Indeed, prior to giving the reader his proposed criminal statute, his concluding chapter lists a number of policy considerations, very carefully going through a number of "crucial issues that courts must analyze" to determine "[t]he significance of particular speech and its potential to lead to destructive behaviors." 32 And yet, it is unclear whether Tsesis wishes to criminalize the very speech he claims is so responsible for the historical harms he describes.

If he would criminalize the statements mentioned above, the implications of his thesis go far beyond misethnic speech. If these statements fall outside the reach of his proposed statute, however, then his thesis is severely compromised. Tsesis claims that "hate speech" caused the Holocaust, American slavery, and Native American removal, and he proposes a statute to criminalize "hate speech." And yet, the "hate speech" that caused the atrocities is not the same as the "hate speech" he would criminalize. By using the same phrase in different ways, he thus fails to notice this inconsistency in his argument.

This problem becomes even more stark when we get to the "hate speech" he discusses in the second section of the book. Because this part of the book argues that "misethnic invective elicits emotional and motivational responses, thereby easing guilt about groupwide mistreatment and injustice," 33 his focus is on the degrading stereotypes that pervade society. Those stereotypes include, for example, "[j] okes targeting ethnic and racial groups"; ${ }^{34}$ hyperboles that "mockingly depict[] [minorities] with thick lips, big noses, and childlike behavior"; 35 Chaucer's portrayal of the " "cursed Jews' kidnapp[ing] and kill[ing] a Christian child" in The Canterbury Tales; Shakespeare's portrayal of Shylock in The Merchant of

29. There is an obvious paradox here of hypothesizing the criminal prosecution of a president, which I will ignore for the moment. I address a related issue below. See infra text accompanying notes $137-46$.

30. Tsesis, supra note 5, at 207.

31. $I d$.

32. TSESIS, supra note 5, at 202.

33. Id. at 5 .

34. Id. at 102 .

35. Id. at 103 . 
Venice; and Dickens's portrayal of "Fagin the Jew as a Satanlike creature." $" 36$

Tsesis writes, "The process paving the way to outrageous acts of injustice is, of course, gradual. It begins by indoctrinating children with the culture of racial and ethnic stratification. ${ }^{, 37}$ This is undoubtedly true, ${ }^{38}$ but what are we to make of it in the context of a book advocating the criminalization of biased speech? Does Tsesis consider The Merchant of Venice "hate speech" or not? I doubt it, particularly given his proposed statute's intent requirement. After all, if Chaucer, Shakespeare, and Dickens constitute proscribable "hate speech," Tsesis's argument amounts to the creation of a substantial police state, ${ }^{39}$ excising large chunks of our cultural heritage, not to mention popular culture. Modern-day book burnings would be trivial in comparison. If, however, his statute does not criminalize such works, he again appears to be undermining his own thesis by effectively demonstrating that the type of speech most likely to "pave[] the way for" atrocities such as the Holocaust and slavery are those that a ban on "hate speech" will not reach because they involve the "culture of racial and ethnic stratification." 40

Another related problem surfaces from this divergence between Tsesis's explicit definition of "hate speech" and the implicit one he uses to draw a connection between "hate speech" and harm. ${ }^{41}$ Recall that the explicit definition, both in its original form and in the proposed statute, includes an intent requirement. ${ }^{42}$ In some sense, this is perfectly understandable. As Tsesis recognizes, a criminal prohibition on speech

36. Id. at 111 .

37. Id. at 106 .

38. See JACK Levin \& JACK McDevitT, Hate CRimes: The Rising Tide OF Bigotry AND BLOODSHED 24-25 (1993) ("Even though verbalized in an apparently harmless joke or an innocuous television sitcom ... stereotypes are often more pernicious than they might at first appear to be. Time and time again, they have been used to justify atrocities committed against members of stigmatized groups.").

39. Cf. Gates, supra note 21, at 54-55 (criticizing Delgado, Matsuda, et al. for "signal[ing] a regime so heavily policed as to be incompatible with democracy").

40. TSESIS, supra note 5, at 106. Indeed, given Tsesis's example of anti-Semitism and the fact that he picks statements in isolation from their social context, it is surprising that Tsesis did not choose to indict the one book that has perhaps been used to justify antiSemitism more than any other-the New Testament.

41. I am indebted to my colleague Richard J. Ross for this insight.

42. The original definition is "antisocial oratory that is intended to incite persecution ...." TSESIS, supra note 5, at $211 \mathrm{n} .1$ (emphasis added). The proposed criminal statute specifically requires that the speaker "intend[] the message to promote destructive behavior." Id. at 207 (emphasis added). In addition, his proposed statute also requires that it be "substantially probable or reasonably foreseeable ... that [dissemination of the speech will] elicit" the discriminatory acts. Id. 
would be unacceptable without such a requirement. ${ }^{43}$ But if it is the potential long-term harm of the speech at which Tsesis is aiming, why should intent matter at all? After all, the thrust of Tsesis's argument is one of long-term cumulative effects-that is, that speech developed over long periods of time can cause harm-and over decades, even centuries, the effects of speech will almost certainly be inadvertent. There is thus a tension between the logic of Tsesis's historical claim, which is rooted in a social science methodology of long-term, inadvertent, cumulative causation, and his proposed solution, which is based in the criminal law and must thus include an intent requirement. ${ }^{44}$

In sum, the disconnection between the "hate speech" that causes the harms Tsesis describes in the book and the "hate speech" that he would criminalize undermines his thesis profoundly, even if one were to accept the premises and logic of his argument. I turn now to the historical premise of his thesis and address his proposal itself in Part IV.

\section{HistoRy, CAUSATION, AND BIASED SPEECH}

\section{A. Historiographical Debates About the Causes of the Holocaust and American Slavery}

Like the stories told by many lawyers, Tsesis's history reads like a legal brief. Unfortunately, however, in order to convey a persuasive story when the facts are somewhat murky, Tsesis's history simply ignores the contrary evidence in the record, a "record" that is, to say the least, vast. There are vigorous debates about the historical claims Tsesis makes. His are not simply claims that the Holocaust happened or that blacks were enslaved in the United States, claims that no serious historian disputes;

43. See id. at 203-04. The proposed statutory definition appears to have several different mens rea requirements: first, what appears to be a negligence standard with respect to the acts being incited (as opposed to the speech itself)—i.e., a requirement that those acts be "substantially probable or reasonably foreseeable"; and, second, the "[intent] to promote destructive behavior" prong, which Tsesis refers to as the "mens rea" requirement. See id. at 203. Unfortunately, because the phrase "destructive behavior" has no definition, it is unclear whether the phrase "intend[ing] the message to promote destructive behavior" is the same as intending to "incit[e] others to discriminate, persecute, oppress, or commit any similar acts." If not, the "intend[ing] the message to promote destructive behavior" language is simply a separate element of the crime, and there is strictly speaking no mens rea requirement for the actual incitement. I discuss the vagueness of the "inten $[\mathrm{t}] \ldots$ to promote destructive behavior" language below. See infra text accompanying notes 153-55.

44. One could perhaps argue that his proposed statute would at least reduce the amount of biased speech, thereby reducing the probability of a future Holocaust. However, as I discuss below, Tsesis fails to show that a reduction in biased speech will reduce the likelihood of any atrocity. At best, all he shows is that a complete elimination of such speech would prevent such an atrocity. See infra Part III.B-C. 
rather, his are claims about linkages and causation, claims that are hotly contested. And yet he writes as though there can be no doubt about the links between the expressions of racist and anti-Semitic ideology on the one hand and the resulting injustices on the other. For this Section of this Review, I do not intend to take sides in any of these historiographical debates, but wish simply to raise a few issues that Tsesis failed to consider-issues that raise serious doubt as to the credence we should give to Tsesis's historical claims in assessing the strength of his ultimate thesis, that we should criminalize biased speech.

Consider first his claim about the Holocaust. The following passage summarizes Tsesis's view of the role of anti-Semitic ideology in the Holocaust:

The German experience contradicts the view that only speech posing an immediate threat of harm is dangerous enough to warrant statutory censure. To the contrary, the most dangerous form of bigotry takes years to develop, until it becomes culturally acceptable first to libel, then to discriminate, and finally to persecute outgroups. The Nazis were able to accomplish what nineteenth- and early twentieth-century anti-Semitic parties could not... only after extensive and prolonged racialist agitation.... Over time, misethnic religious and secular beliefs catalyzed a murderous ideology, supported by the majority of the German public. Early German ideology, which denounced Jews for not adopting Christianity, gave way to an even more combustible view that attributed to them an implacable and biological evil.

While Tsesis's argument digs deep into the German past, drawing on anti-Semitic ideology as far back as the Middle Ages, ${ }^{46}$ he makes virtually no reference to the Versailles Treaty, the hyperinflation of the 1920s, the

45. TSESIS, supra note 5, at 26-27 (footnotes omitted).

46. Perhaps the most telling example of Tsesis's focus on expressions of anti-Semitic ideology as the "cause" of the Holocaust is the following passage:

Hitler's diabolical plan and its implementation [i.e. the Holocaust] should be compared with Luther's ominous directives of how to deal with Jews. Take, for example, Luther's advocacy of the burning of synagogues; nearly four hundred years after his pronouncement, when ancient anti-Jewish sentiments were at their apex, the Nazis and their sympathizers did just that [referring to Kristallnacht].

Id. at 25

Comparing "Hitler's diabolical plan and its implementation" to a book written by Luther 400 years earlier demonstrates a confusion between speech and action. There is simply no comparison whatsoever between the words Luther used in his book and the "implementation [of Hitler's diabolical plan]," which consisted of the actual systematic killing of six million Jews by a secular, immoral regime. I doubt that Tsesis really believes that Luther's words should be compared with the Nazis' actions, as such an argument would be open to serious problems. Cf. Gates, supra note 21, at 53-54 (criticizing proponents of hate speech regulations for conflating racism with the expression of racism). What he is pretty clearly saying, however, is that society should criminalize words because of the possibility that they could have an impact, even if that impact occurs as much as 400 years later. 
mass carnage and traumatic impact of Germany's defeat in World War I, the strength of the Social Democratic Party prior to the Third Reich, the special role of Austrians in both the formulation and the implementation of the Holocaust, ${ }^{47}$ the fear of communism in the wake of the Russian Revolution, or any number of other social and economic factors that are commonly considered to have contributed to the Holocaust. ${ }^{48}$ While " $[\mathrm{n}] \mathrm{o}$ serious German historian discounts the legacy of German anti-Semitism,",49 Tsesis makes a number of highly contested claims without acknowledging the disagreement among historians. As one scholar put it, "Historians, motivated by the conviction that racial hatred alone is not enough to explain the murder of six million human beings, have spent decades studying a whole set of causes that resulted in the extermination of Europe's Jews." 50

Tsesis's failure to grapple with this historiographical debate affects both minor and fundamental parts of his thesis. Take for example his claim that "National Socialists had advocated [the Final Solution] even before Hitler became German Chancellor in 1933." ${ }^{, 51}$ With nary a citation, this statement sweeps away one of the most disputed issues in the historiography of the Holocaust. ${ }^{52}$ While this assertion is hardly important to his ultimate claim, its presence in the book suggests that we should be skeptical of his other claims.

47. Most famously, of course, Hitler was Austrian, not German, and did not move to Germany until just before the outbreak of World War I. Charles BRACELEN Flood, Hitler: The PATH To Power 6, 12 (1989). In fact, he did not even become a German citizen until just before he challenged Hindenburg for the presidency in 1932. JOHN TOLAND, ADOLF HITLER 261 (1976).

48. See Robert S. Wistrich, Helping Hitler, Commentary, July 1996, at 29. Tsesis occasionally makes reference to the social and economic conditions of Weimar Germany but does so as though these conditions were mere happenstance. See, e.g., TSESIS, supra note 5, at 110 ("[T]he catastrophe of losing World War I and the hyperinflation that followed brought age-old hatreds to the surface, enabling Hitler and his henchmen to win broad-based, sustained support."). In addition, he makes no mention of the fact that both Imperial and Weimar Germany had an incitement-to-hatred law similar to the one he proposes. See infra text accompanying notes 62-66.

49. Norman G. Finkelstein, Daniel Jonah Goldhagen's “Crazy” Thesis: A Critique of Hitler's Willing Executioners, in NORMAN G. FINKELSTEIN \& RUTH BETTINA BIRN, A NATiOn ON Trial: The Goldhagen Thesis AND Historical Truth 1, 14 (1998).

50. EnZo Traverso, Understanding the NAZI Genocide: MARXISM After AusChWITZ 91 (Peter Drucker trans., Pluto Press 1999).

51. TSESIS, supra note 5, at 25.

52. See Finkelstein, supra note 49 , at $16-17$ (noting that the dispute between whether "Hitler sought from the outset (the intentionalist school) or was pressed by circumstances (the functionalist school) to exterminate the Jews" is a "key controversy in the Nazi holocaust literature"). 
Or consider his uncritical reliance on Daniel Goldhagen's best-seller Hitler's Willing Executioners. He relies on the book for claims about the broad participation of "ordinary Germans" in the implementation of the Holocaust, ${ }^{53}$ a claim more fundamental to his thesis since he argues that anti-Semitic attitudes dating back to the Middle Ages that permeated German culture ultimately led to the Holocaust. It is hard to understand how he could ignore the fact that dozens, if not hundreds, of academic historians have roundly rejected Goldhagen's thesis. ${ }^{54}$ For him to rely on Goldhagen without even acknowledging either the international furor raised by Goldhagen's book or the almost universal rejection of Goldhagen's thesis by professional historians suggests serious gaps, if not outright errors, in Tsesis's historical claims.

His next claim is that racist ideology led to slavery. He is careful never explicitly to say racism caused slavery, but it is hard to understand how he can avoid claiming some kind of causal relationship if his ultimate argument is that expressions of racist ideology should be proscribed because they "pave[d] the way" for slavery. ${ }^{55}$ Even stated weakly, however, as simply a temporal claim that racist ideology preceded statesanctioned slavery, Tsesis's claim is highly contested by historians. Indeed, the origins of American slavery and the role racist ideology played have been the subject of historical debate for nearly a century. ${ }^{56}$ Some historians argued that slavery originally appeared as a response to economic need and

53. TSESIS, supra note 5, at 26.

54. See, e.g., TRAVERSO, supra note 50, at 91 ("The US and German historical communities have almost unanimously declared [Goldhagen's] book inadmissible as serious historical argument."). See also, e.g., WILliam BRUSTEIN, THE LOGIC OF EVIL: THE SOCIAL ORIGINS OF THE NAZI PARTY, 1925-1933 (1996); Finkelstein, supra note 49; Robert E. Herzstein, Daniel Jonah Goldhagen's "Ordinary Germans": A Heretic and His Critics, 2 J. HisT. SOC'Y 89 (2002) (reviewing six books that criticize Goldhagen and further noting that historians have been critical of his thesis); Gustav Jahoda, "Ordinary Germans" Before Hitler: A Critique of the Goldhagen Thesis, 29 J. INTERDISCIPLINARY HIST. 69 (1998).

55. TSESIS, supra note 5. Indeed, it is not always clear whether he is arguing that racism led to slavery or was a post-hoc justification once slavery was in place. For example, at one point, he emphasizes the fact that certain hate speech preceded the state-sanctioned institution of slavery (and therefore could at least arguably be seen as playing some causal role in that institution). Id. at 29. At another point, he notes that hate speech played a role "in justifying the institutionalization of hereditary servitude." Id. at 28 (emphasis added). Despite this ambiguity, Tsesis's central thesis requires the former claim-in order to argue that hate speech "paves the way for harmful social movements," as the title of his book suggests, he needs to say that racism led to, or in some way caused, slavery, not the other way around. Otherwise, how else could outlawing racist ideology, as he suggests, do anything to prevent a future calamity such as slavery? I discuss the nature of Tsesis's causal claim in Part III.B.

56. See William M. Wiecek, The Origins of the Law of Slavery in British North America, 17 CARDOZO L. REV. 1711, 1749 (1996). 
that the racial justification for it emerged only later, ${ }^{57}$ while others argue that slavery was a product of racism. ${ }^{58}$ This debate is referred to by contemporary historians as the "chicken-egg" debate because of a widespread view that the question of which came first, racism or slavery, is irresolvable. ${ }^{59}$ Tsesis simply ignores the debate and instead conveniently chooses to rely on the historians and evidence that support his claim. ${ }^{60}$

Lest I be misunderstood in my critique of Tsesis's history, let me be clear about a few things. First, I do not question what most would consider obvious connections between misethnic ideology and the horrific events Tsesis discusses. It is virtually beyond dispute that anti-Semitism played some role in the Holocaust, that racism was connected in some way to American slavery, and that misethnicity was somehow involved in the U.S. policy of expelling indigenous Americans from their land.

Second, I am not arguing that Tsesis is wrong about his historical claims, since I have not canvassed the primary sources necessary to address such a claim. I am simply suggesting that he has failed to engage the historiographical debates on these issues. Thus, the book's historical claims should be viewed with suspicion.

Finally, let me be clear that I do not view this critique of Tsesis's history by itself as crucial to the ultimate point of the historical examples he raises. Under ordinary circumstances, social policy need not be limited to addressing the sole cause-or even the most important cause-of social ills if implementing a particular policy is likely to prevent or reduce the likelihood of the harm. It thus cannot be enough to respond to Tsesis's call for a ban on speech by nitpicking at his history, since he undoubtedly is correct that racist ideology has played some role in the perpetuation of oppression throughout history. As I explain in the remainder of this Review, however, Tsesis's history does not help us understand either what type of role such ideology plays or more importantly what role his proposed statute (or any similar such law) might play in reducing the likelihood of future harm.

57. See, e.g., Edmund S. Morgan, American Slavery, American Freedom: The ORdeAl of COLONIAL VIRGinia (1975); Oscar \& Mary F. Handlin, Origins of the Southern Labor System, 7 WM. \& MARY Q. 199 (1950).

58. See Winthrop D. Jordan, White Over Black: American AtTitudes Toward THE Negro, 1550-1812 (1968); Carl N. Degler, Slavery and the Genesis of American Race Prejudice, 2 COMP. STUdies IN SOC'y \& Hist. 49 (1959).

59. See generally Wiecek, supra note 56, at 1748-49, n.136.

60. Indeed, like a lawyer writing a brief, Tsesis's only acknowledgement of the complex historiographical debate involving the relationship between racism and the origins of American slavery consists of a "but see" citation to one of Oscar and Mary Handlin's articles. See TSESIS, supra note 5, at 213 n.3. 


\section{B. Causation Theory and the Claim that Biased Speech Causes Long-Term Harm}

Because Tsesis argues that this historical record justifies a prohibition on biased speech, he needs to be able to make some kind of claim about the counterfactual situation-he needs to be able to say that his suggested changes to law, had they been adopted at some point in the past, would have either prevented or reduced the likelihood of injustices such as the Holocaust or American slavery. ${ }^{61}$ To do this, Tsesis's argument requires some kind of a causal claim.

To the extent that he makes such a claim, however, he runs into two difficulties that he simply glosses over: First, law does not operate in a vacuum, and the effectiveness of a prohibition of biased speech in actually suppressing such speech is highly questionable. Second, because he has failed to recognize that the relationship between biased speech and the injustices he describes cannot be divorced from the social and economic conditions in which the atrocities took place, the causal claim that he makes does little to justify his proposed solution - a ban on biased speech.

One example should suffice to illustrate my first point. Both Imperial and Weimar Germany had hate-propaganda laws similar to the anti-biased speech law Tsesis proposes, ${ }^{62}$ and "those laws were enforced with some vigour." 63 In 1925, the Bavarian government even banned speeches by Hitler - a ban that it was forced to revoke soon thereafter when the Nazis "distribut[ed] a drawing of Hitler gagged, with the caption, 'One alone of 2,000 million [sic] people of the world is forbidden to speak in

61. Or that by adopting them today, we would reduce the likelihood of such events in the future.

62. Indeed, there is a certain irony when Tsesis says that "Germany has passed several laws designed to allay the short- and long-term risks of unchecked hate speech." TSESIS, supra note 5, at 187 (emphasis added). At least one of the criminal provisions that Tsesis praises, the incitement-to-hatred provision (Section 130 of the German Federal Criminal Code), derives from a predecessor incitement-to-hatred statute in the Imperial German Criminal Code. See Eric Stein, History Against Free Speech: The New German Law Against the "Auschwitz"-and Other-“Lies," 85 Mich. L. REV. 277, 282 (1986); see also Ambrose Doskow \& Sidney B. Jacoby, Anti-Semitism and the Law in Pre-Nazi Germany, 3 CONTEMP. JEWISH REC. 498, 503 (1940).

63. A. Alan Borovoy, When Freedoms Collide: The Case for Our Civil Liberties 50 (1988). "During the fifteen years before Hitler came to power, there were more than two hundred prosecutions based on anti-semitic speech." Id. These included prosecutions against some notable Nazis whom Tsesis describes as purveyors of "hate speech," including Theodor Fritsch, Joseph Goebbels, and Julius Streicher. TsEsIS, supra note 5, at 19-20, 24, 25. See Doskow \& Jacoby, supra note 62, at 502-03, 505. Indeed, even the statement "The Jews are our misfortune!"-a quintessential example of what Tsesis calls "hate speech"had been forbidden by a court injunction in the years before Hitler came to power. TSESIS, supra note 5, at 18 (referring to the phrase as "a painful dart with slow-acting poison"); Doskow \& Jacoby, supra note 62, at 508 . 
Germany." 64 Some opponents of "hate speech" laws have argued that this alone should be enough to convince us not to adopt such laws, ${ }^{65}$ but this is not my point. Rather, my point is simply that the change in law Tsesis suggests would not necessarily even reduce the amount of biased speech in a society, let alone reduce the likelihood of a future Holocaust, since we know that there was a good deal of such speech in pre-Nazi Germany at a time when a variation of his proposal was the law. ${ }^{66}$

As for my second point, we need to look more closely at exactly what sort of causal connection Tsesis alleges between the speech and the harm. Before doing this, let me step back for a moment and look broadly at three different types of causal claims that could be made about the relationship between biased speech and the atrocities Tsesis describes. ${ }^{67}$ Doing so will allow us to understand not only what Tsesis's argument does claim, but also what it does not.

One approach to saying that biased speech causes harm would be to rely on what is known as "deterministic" or "logical" causation. ${ }^{68}$ The statement " $\mathrm{C}$ is a cause of $\mathrm{E}$ " means simply that " $\mathrm{C}$ is one of a set of individually necessary and jointly sufficient conditions for the occurrence of E. .. [I]f any one member of the set [which I will designate $\mathrm{C}(\mathrm{d})$ ] is absent, E will never occur. If every member of $[\mathrm{C}(\mathrm{d})]$ is present, $\mathrm{E}$ will always occur." ${ }^{, 69}$ In this sense, if we were to denominate biased speech $\mathrm{C}_{1}$, and perhaps a whole host of other known and unknown social, historical, and cultural factors $C_{2}$ through $C_{n}$, this approach amounts to saying that biased speech "causes" harm because it is a logically necessary (though not sufficient) condition for the harm. One thing to note here-and I will return to this in a moment-is that, in this approach to causation, because each

64. Aryeh Neier, Defending My Enemy: American Nazis, the Skokie Case, and THE RISKS OF FREEDOM 165 (1979).

65. See, e.g., id.; Regina v. Keegstra, [1990] 3 S.C.R. 697, 829, 856-57 (McLachlin, J., dissenting); Borovoy, supra note 63. Cf. Doskow \& Jacoby, supra note 62, at 498 ("It is arguable that the judicial machinery is essentially inappropriate for the suppression of a political movement, that prosecutions make martyrs of the defendants and give them new audiences but do not deter them or others from carrying on their agitation.").

66. "The German experience... demonstrates that a set of rules in the books, coupled with organized private effort to secure enforcement, provides no barrier to the triumph of a fanatical campaign to pin the woes of a nation upon a helpless minority." Doskow \& Jacoby, supra note 62, at 509.

67. My taxonomy here is lifted wholesale from Frederick Schauer's article on causation and sexual violence. See Frederick Schauer, Causation Theory and the Causes of Sexual Violence, 1987 AM. BAR FOUND. RES. J. 737, 742-54.

68. This approach is most commonly associated with David Hume and, in a variation that is not important here, John Stuart Mill.

69. Schauer, supra note 67 , at $742-43$. 
and every "cause" is necessary to the effect, it is logically no more helpful to say $C_{1}$ causes $E$ than to say $C_{2}$ or any other member of $C(d)$ causes $E$.

A second type is what Frederick Schauer refers to as "attributive" causation. Variations on this approach are familiar to lawyers, as they are commonly used in tort and criminal law. The idea here is to start with deterministic causation, but then to take it a step further and choose among the logically equivalent causal candidates - that is, among the set $\mathrm{C}(\mathrm{d})$ one or a few that seem really causal. How we "attribute" causation to one of the logical causes rather than another is, of course, a difficult task, but it is important that there be "some reason for selecting some rather than other causes for this attribution." ${ }^{\text {" N0 }}$ Not surprisingly, philosophers and legal scholars have been grappling with this problem for quite some time. Schauer cites two prominent approaches, and for my purposes, this will suffice. One method, associated with H.L.A. Hart and Tony Honoré, is to rely on the "common sense" notion of "cause," which they argue amounts to choosing among the set of causes only those that are unusual or "abnormal." A1 A second methodology, which Schauer ascribes to Guido Calabresi, is to choose among the set of logical causes "those pressure points that are most amenable to the social goals we wish to accomplish.,"72 Put another way, since we begin our inquiry about causation with the knowledge that we intend to use our conclusion to advocate legal change, we choose from among the logical causes "those it is reasonable to suppose the legal system can do something about, whether by way of deterrence or otherwise." 73 So one way to characterize this in our context would be to argue that biased speech should be treated as either unusual or somehow more amenable to legal change than any of the other possible causes of an atrocity such as the Holocaust.

For Schauer's third type of causation, we need to put aside our conception of deterministic or logical causation. Most variations on logical causation, including those I have referred to as "attributive," tend to focus on determining the cause of a single effect. So they can be quite helpful if we ask, perhaps, what caused Kristallnacht as a singular event on the night of November 9, 1938. To answer the question, we might inquire about the

70. Id. at 747. $1985)$.

71. See generally H.L.A. Hart \& TONy HonOrÉ, CAUSATION IN THE LAW $26-61$ (2d ed.

72. Schauer, supra note 67, at 748 n.25 (quoting Guido Calabresi, Concerning Cause and the Law of Torts, 43 U. CHI. L. Rev. 69, 106 (1975)); see also Felix S. Cohen, Field Theory and Judicial Logic, 59 YALE L.J. 238, 252 (1950) ("What we actually do when we look for a legal cause is to pick out of this infinity of intersecting strands a useful point at which public pressure can be placed." (citations omitted)).

73. Schauer, supra note 67, at 748 (citations omitted). 
set $\mathrm{C}(\mathrm{d})$ and then ask, for example, whether Luther's 1543 book On the Jews and Their Lies (which is hard to read without being reminded of the very burning of synagogues that took place on Kristallnacht) is a member of that set, and then ask whether we should hold Luther responsible for Kristallnacht because his book is a particularly important member of that set. In contrast, if we are interested in "trying to determine what types of events, as classes"-for example, biased speech-"produce what types of events, as consequences" 74 - for example, genocide-it makes more sense to look to what Schauer refers to as "probabilistic" causation, an approach to causality that is central to the methodology of the social sciences.

Under a probabilistic account of causation, a causal relationship exists, for types or classes, insofar as the putative cause increases the incidence of the effect, and a causal relationship exists, in particular cases, insofar as the putative cause increases the probability of the effect. ... [U]nder any version of probabilistic causation the goal is to look for factors that enable us to say that $\mathrm{E}$ is more likely, or more probable, when $\mathrm{C}$ is present than when $\mathrm{C}$ is not.

With this background, let us return to Tsesis's claim. Since he relies on historical—in his words, "empirical" "77—evidence, one would expect him to use probabilistic causation - that is, to make some kind of a claim that biased speech increases the likelihood of horrors such as the Holocaust. But if we look both at the way he actually articulates his claim and his methodology, he appears simply to be making a claim about logical, or deterministic, causation: biased speech is a "cause" of the Holocaust, Tsesis tells us, because it is a necessary condition for the Holocaust. $^{78}$

What should we conclude from this? First, as intuitive as this conclusion sounds, ${ }^{79}$ it tells us practically nothing: biased speech has been

74. Id. at 751 .

75. Id. at 752 .

76. Id. at $752-53$.

77. Tsesis's law review article on which the book was based was entitled "Empirical Shortcomings of First Amendment Jurisprudence." See TSESIS, supra note 5, at ix.

78. See id. at 170 ("Although hate speech does not always lead to organized supremacism, it is a necessary ingredient to that end."). Other examples of Tsesis characterizing biased speech as simply a background condition necessary for the atrocities include the following statements: "The hatreds . . . will not always burgeon into action. For that, social strains have to be at a peak. But they will lie dormant until the season is right for the noxious ideas to bud into violence." Id. at 172. "Although most barking (antilocution) does not lead to biting, yet there is never a bite without previous barking." Id. at 102 (quoting Gordon Allport, The NAtURe of PReJudice 57 (25th Anniversary ed. 1979)) " $[\mathrm{H}]$ einous crimes can be committed anywhere misethnicity has donned the raiment of acceptable dialogue." Id. at 6 (emphasis added).

79. To start, let me say that it strikes me as almost definitely correct. Nonetheless, because his history ignores the social, cultural, and economic factors that undoubtedly 
around since history began. As a logical matter, then, it is no more helpful to say that anti-Semitic speech caused the Holocaust than to say organized government caused it, or, for that matter, to say that oxygen caused it. All were necessary ingredients, but all have been present in every historical epoch in every country in the world. Second, even if it is not true that there has been biased speech in every society from time immemorial, it is hard to imagine anyone disagreeing with Tsesis's historical premise if the claim is merely that biased speech was a necessary condition for the atrocities that followed. ${ }^{80}$ However, as James Weinstein has put it:

[I]t does not [thereby] follow... that the increase in racist beliefs caused by the speech that proponents of hate speech legislation would suppress will lead to the reinstitution of slavery, legally imposed racial segregation, or genocide.... There would have to be far-reaching changes in American society and institutions before racist beliefs could lead to such enormous injuries.

Deterministic causation is thus not particularly helpful. Beyond deterministic causation, what else might Tsesis be saying? His argument

played at least some role in each of the injustices he describes, Tsesis has failed to make the case even for deterministic causation. In fact, he may well have made the classic error of confusing correlation with causation. When ice cream sales go up, so, too, does the amount of bare skin one sees at the beach. If correlation were causation, those who sought to keep bare skin from plain view could call for a ban on ice cream sales and feel confident their goal would be accomplished. The problem, of course, is that, while there is a strong correlation between bare skin and ice cream sales, there is not likely to be a causal connection at all. Rather, both are, in turn, caused by a third independent factor, namely warm weather.

Tsesis's claim may well suffer this same logical flaw. He claims a linkage between biased speech on the one hand and the Holocaust or slavery on the other. Yet he ignores one possible connection between biased speech and the injustices he describes-both biased speech and the injustices are caused by an independent third factor, namely the background economic and social conditions. Of course, this is likely a gross oversimplification. The links are no doubt far more complex. But because Tsesis in effect treats biased speech as an exogenous variable (the "spark") to be inserted into history waiting for social and economic conditions to cause the harm (the "flame" or the "conflagration"), he has failed to address the question of whether biased speech (or, at least, an increased incidence of the type of biased speech that might lead to concrete harms) might itself be a result of certain social and economic conditions. Id. at 139 (quoting Gitlow v. New York, 268 U.S. 652, 669 (1925)).

80. Even those generally viewed as skeptical of banning "hate speech" recognize this fact. See, e.g., WEINSTEIN, supra note 11, at 131 ("[I]t is undeniable that catastrophic injuries to racial or ethnic groups such as slavery and segregation in the United States or the Holocaust in Europe could not have occurred in the absence of widespread racist beliefs...."). See also infra Part IV.A. (discussing American Booksellers' Ass'n v. Hudnut, 771 F.2d 323 (7th Cir. 1985)). As I noted above, I consider it almost a given that racist ideology has played some role-perhaps even a significant one-in perpetuating inequities against minorities in this country and abroad, including in each of the historical examples Tsesis gives.

81. WeInSteIn, supra note 11, at 131; $f$. Floyd Abrams, Hate Speech: The Present Implications of a Historical Dilemma, 37 VILL. L. REV. 743, 754-55 (1992). 
appears to be implicitly relying on some form of what Schauer refers to as attributive causation, ${ }^{82}$ but he gives us little reason to attribute causation to speech rather than any number of social, cultural, economic, and/or political factors. Perhaps he believes that biased speech is, in Calabresi's words, one of those "pressure points that are most amenable" 83 to the goal of reducing the possibility of a future Holocaust. If so, however, he provides no evidence of this, and, as I described earlier, ${ }^{84}$ the German experience prior to the Third Reich provides at least some anecdotal evidence to suggest that biased speech is not particularly susceptible to pressure from a legal system, and that criminalization would do little to prevent a horrific event such as the Holocaust.

Let us ignore this anecdotal evidence, however, and give Tsesis's arguments the benefit of the doubt. There is, after all, something intuitive about blaming racist ideology for systemic crimes such as the Holocaust and American slavery, crimes that seem so obviously linked to attitudes about racial inferiority. Therefore, let us assume that, among the multitude of necessary conditions for a future genocide or institutional slavery, biased speech is one of the more important ones. Even if we make this assumption, however, it does not advance Tsesis's argument very far: he may have made an argument based on deterministic causation or on some form of attributive causation, but he has clearly not made one based on probabilistic causation. This is clear for two reasons: First, nowhere does he articulate the claim as one about probabilistic causation. Second, and more important, his methodology simply does not allow a claim about probabilistic causation. He has not even attempted to ask-let alone answer-the question of whether there is any probabilistic relationship between biased speech (the hypothesized independent variable) and longterm harm (the hypothesized dependent variable). To even begin to make an empirical claim about the relationship between biased speech and longterm harm, one needs to ask the question comparatively. I explore this theme in the next Section.

82. Here is one example of what appears to be the implication that biased speech is particularly important among the causes: "Overwhelming historical, psychological, and sociological evidence demonstrates that hate speech has been and continues to be instrumental in initiating and perpetuating great human injustices." TSESIS, supra note 5, at 193 (emphasis added).

83. Schauer, supra note 67, at 748 n.25 (quoting Guido Calabresi, Concerning Cause and the Law of Torts, 43 U. CHI. L. REV. 69, 106 (1975)).

84. See supra text accompanying notes 62-66. 


\section{The Need for Comparative Analysis}

The penultimate chapter of Tsesis's book gives a brief survey of the wide variety of countries that have adopted hate-speech legislation and concludes that U.S. jurisprudence is "anomalous." 85 Drawing on the experiences of other countries is becoming increasingly common in debates about a whole host of policy questions, from health-care policy ${ }^{86}$ to labor market flexibility, ${ }^{87}$ and it is in general a trend I applaud. When used properly, a comparative analysis can lead to insights that are more useful than those derived from ideological positions about the "free market" or, for example, being "tough on crime." If a common policy goal can be

85. TSESIS, supra note 5, at 192. Others have also noted American exceptionalism in this area. See, e.g., LeE C. Bollinger, The Tolerant Society: Freedom OF SPEECH AND EXTREMIST SPEECH IN AMERICA 38 (1986) ("It seems a significant piece of corroborating evidence that virtually every other western democracy does draw such a distinction in their law; the United States stands virtually alone in the degree to which it has decided legally to tolerate racist rhetoric."); SAMUEL WALKER, HATE SPEECH: THE History OF AN AMERICAN CONTROVERSY 159 (1994); Kathleen Sullivan, Freedom of Expression in the United States: Past and Present, in THE BOUNDARIES OF FREEDOM OF EXPRESSION \& ORDER IN AMERICAN DEMOCRACY 1, 9 (Thomas R. Hensley ed., 2001); Credence Fogo-Schensul, Note, More Than a River in Egypt: Holocaust Denial, The Internet, and International Freedom of Expression Norms, 33 GoNZ. L. REV. 241, 247 (1997-98).

86. See, e.g., Eric Beaudan, Canadian Model of Healthcare Ails, CHRISTIAN ScI. MONITOR (Aug. 28, 2002), available at http://www.csmonitor.com/2002/0828/p01s04wogi.html (last visited Jan. 30, 2003).

87. Compare, e.g., International Monetary Fund, World Economic Outlook 88-121 (1999), available at http://www.imf.org/external/pubs/ft/weo/1999/01/0599ch4.pdf, with John Schmitt \& Jonathan Wadsworth, Is the OECD Jobs Strategy Behind US and British Employment and Unemployment Success in the 1990s? (2002) (unpublished paper prepared for "Liberalization and Employment Performance in the OECD," CEPA, New School University, May 18-19, 2001) (on file with Journal). If Tsesis wanted to argue that regulation of biased speech is a moral question and that the fact that many other countries have adopted such legislation evidences a growing international consensus on the issue, Tsesis could presumably draw on the Supreme Court's recent changes in Eighth Amendment death penalty jurisprudence. See, e.g., Atkins v. Virginia, 122 S. Ct. 2242, $2249-50$ n.21 (2002); Stanford v. Kentucky, 492 U.S. 361, 369 n.1 (1987); id. at 389 (Brennan, J., dissenting). One of the best recent examples of the deep divide as to the merits of considering foreign court decisions in Eighth Amendment jurisprudence was the Court's recent denial of certiorari in the Charles Foster case, involving the question of whether an extraordinarily long delay before execution violates the Eighth Amendment. Compare Foster v. Florida, 123 S. Ct. 470, 472 (2002) (Breyer, J., dissenting from denial of certiorari) (noting the Canadian Supreme Court's decision to consider a lengthy delay in executions in the United States as a factor to consider in extraditions) with id. at $470 \mathrm{n}$.* (Thomas, J., concurring in denial of certiorari) ("While Congress, as a legislature, may wish to consider the actions of other nations on any issue it likes, this Court's Eighth Amendment jurisprudence should not impose foreign moods, fads, or fashions on Americans."). See also generally Anne-Marie Slaughter, A Typology of Transjudicial Communication, in InTERNATIONAL LAW DeCisions In NATIONAL CourTs 37 (Thomas M. Franck \& Gregory H. Fox eds., 1996). 
agreed upon, ${ }^{88}$ one can use comparative data to begin to understand which policies might best further that goal. Drawing on the diverse experiences of other countries with similar policy problems can thereby help in the search for solutions to these problems.

Unfortunately, however, Tsesis's reliance on the speech regulations of other countries fails to advance our understanding of whether a prohibition on racist ideologies is a good thing. He does little more than assert that the United States is wrong and the rest of the world is right and then simply concludes the book with a one-size-fits-all statutory provision. ${ }^{89}$ This is a shame because, by looking at other countries, one might be able to learn something about the importance of history and social context in the broader question of "hate speech" regulation. For example, a nation's historical legacy might have an impact on the merits of speech restrictions in particular countries, and in particular on whether specific "historically persecuted groups" might warrant specific legislation in individual countries $;{ }^{90}$ or, a more careful look at social and historical context might

88. I certainly do not mean to imply that this is a trivial step.

89. In a literal sense, he proposes two different statutes-one "for European countries whose experience with the dangerous effects of misethnic messages is extensive" and a second which he believes would have "a greater likelihood of passing" in the United States. TSESIS, supra note 5, at 207. His second statute simply replaces the phrase "historically persecuted group" with the phrase "identifiable group," perhaps because he suspects the latter phrase would be less open to constitutional attack. (As I note below, see infra Part IV, both statutes would fail under Brandenburg.) Nonetheless, his critique of U.S. doctrine suggests that the second statute is simply an attempt to incorporate portions of that doctrine notwithstanding a disagreement with it. In any event, the two statutes are effectively the same for the purposes of my current argument. I discuss the details of the statutes below. For now, however, let me note that Tsesis clearly favors the first and seems to believe that this proposed statute would reduce the likelihood of a future calamity such as slavery or the Holocaust.

90. It might be one thing for the United States to look to the impact of legislation outlawing anti-Semitic ideology in Canada, for example. See, e.g., Kent GreEnAwALt, Fighting Words: Individuals, COMMUNiTIES, AND Liberties OF SPEECH 47-70 (1995) [hereinafter GREENAWALT, FIGHTING WORDS]. It would be another thing altogether to look to the impact of, or rationale for, such laws in Germany or in Israel. In Germany, for example, a simple denial of the Holocaust violates the law. See $\S 130$ Nr. 3 StGB (German Penal Code), available at http://www.iuscomp.org/gla/statutes/StGB.htm\#130. But, on the question of laws prohibiting expressions of anti-Semitic ideology, one simply cannot generalize from German law to that of the United States, notwithstanding Tsesis's desire to do so. See TSESIS, supra note 5, at 188 . As one German commentator has recently put it, the law prohibiting Holocaust denials "cannot be justified along the lines of traditionally accepted free speech doctrine. It can be justified only against the background of the singular significance of the Holocaust to the self-image of all Germans." Winfried Brugger, Ban On or Protection of Hate Speech?: Some Observations Based on German and American Law, 17 Tul. EuR. \& Civ. L.F. 1, 18 (2002) (emphasis added). Commentators have begun to analyze the broader policy question of "hate speech" regulation in a comparative manner. See, e.g., Fogo-Schensul, supra note 85; Bradley A. Appleman, Note, Hate Speech: A Comparison of the Approaches Taken by the United States and Germany, 14 WIS. INT'L L.J. 
help elucidate how "hate speech" regulation fits into the broader role that law in general plays in particular countries. ${ }^{91}$

Ultimately, it may be that part of what is shaping Tsesis's approach is an attempt-perhaps even a subconscious one-to suppress racist ideology because he sees racist views as wrong in an objective sense. ${ }^{92}$ When he discusses slavery, for example, he says, "The folk belief in the economic benefits of slave labor turns out to have been as spurious as all other dogmas built on misethnicity." 93 While he may well be correct that the economic benefits of slave labor in the context of the American South were overstated, the way he makes his claim shows that he views the supporting economic studies he describes as almost secondary to the fact that a claim about the economic benefits of slave labor is a "dogma[] built on misethnicity." 94

422 (1996); Michel Rosenfeld, Hate SPeECh in Constitutional JuRisprudence: A COMPARATIVE ANALYSIS (Cardozo Law Sch. Jacob Burns Inst. for Advanced Legal Studies, Working Paper Series No. 41, 2001), at http://papers.ssrn.com/sol3/papers.cfm?abstract_id= 265939; Sionaidh Douglas-Scott, The Hatefulness of Protected Speech: A Comparison of the American and European Approaches, 7 WM. \& MARY BILL RTS. J. 305 (1999); Greenawalt, Fighting Words, supra; Under the Shadow of Weimar: Democracy, LAW, AND RACIAL INCITEMENT IN SiX COUNTRIES (Louis Greenspan \& Cyril Levitt eds., 1993); Striking a Balance: Hate Speech, Freedom of Expression and NonDISCRIMINATION (Sandra Coliver ed., 1992). If Tsesis had attempted to place the issue in the social and historical context of a particular country rather than proposing a single law that fails to account for the different circumstances in different countries, he might have been able to use his deep foray into historical research to inform this dialogue.

91. See, e.g., James Q. Whitman, Enforcing Civility and Respect: Three Societies, 109 YALE L.J. 1279 (2000) (arguing that "hate speech" regulations in France and Germany must be viewed as part of the broader role that respect and civility play throughout the law of those countries).

92. One can certainly argue that racist ideology should be proscribed for its own sake based on at least two different rationales. First, one can argue that racist ideology should be outlawed because it is simply wrong in an objective sense. Cf., e.g., Wright, supra note 11, at 10 (arguing that the "law should not ignore what a hard-won societal consensus has established as the elemental wrongness of the use of racial epithets"). Second, one could also argue that such speech should be proscribed based on the expressive value of the lawthat is, because the law represents an expression of society's collective values. See, e.g., Matsuda, supra note 11, at 2379-80 ("In a society that expresses its moral judgments through the law, and in which the rule of law and the use of law are characteristic responses to many social phenomena, this absence of laws against racist speech is telling."). Neither of these, however, is Tsesis's argument for a criminal statute. Rather, his claim is that we should criminalize biased speech because the harms it engenders are concrete and significant.

93. TsESIS, supra note 5, at 45.

94. Here are a few other telling examples suggesting that Tsesis believes that racist views are themselves the problem. In his chapter on the U.S. policy of expelling indigenous Americans from their land in the mid-nineteenth century, he says: "Voices opposed to removal were audible through the din of mischaracterizations, but the truths they enunciated and the democratic themes they sounded were not triumphant in the marketplace of ideas." 
Since Tsesis already appears to be certain that "all dogmas built on misethnicity" are spurious and that "aggressive ideology" necessarily results in an inaccurate depiction of its targets, he doesn't feel the need to ask the more interesting questions that arise when the issue of hate-speech legislation in other countries is raised: Are outgroups better off in a regime that prohibits "hate speech"? Are they less likely to suffer hate crimes (either defined as individually motivated bias crimes or mass systemic crimes such as genocide or slavery)? Are "harmful social movements" less likely to arise? That Tsesis doesn't conduct a thorough study of these questions can of course be excused; no book can do everything. But he unfortunately fails even to ask these questions and instead simply assumes that regimes with criminal prohibitions of "hate speech" are better for "outgroups."

While I don't know the answers to any of these questions, I imagine the issue is quite complex. I also suspect that the correlation between hate-speech legislation and a lower incidence of hate crimes, if even positive, is probably slight. ${ }^{95}$ And one would have to show, at the very least, that the correlation is positive before one could make even a prima facie case for "hate speech" legislation based on this sort of rationale. Moreover, if one is looking for "pressure points that are most amenable to" ${ }^{96}$ government influence, I imagine that economic growth, social welfare protection, levels of housing integration, public financing of educational opportunities, or any number of social and/or economic factors are better candidates. This is likely to be so not only because I suspect these factors have a significantly higher correlation with the incidence of hate crimes (again, no matter how defined) than the presence of "hate speech"

Id. at 61. Or consider this broader statement: "Rather than enlightening listeners through accurate depiction of its subjects, hate speech menaces outgroups through false characterizations and aggressive ideology." $I d$. at 200 . He is almost certainly correct, as a factual matter, that certain expressions of "hate speech" in certain contexts "menace[] outgroups." For social science research supporting this point, see Laura Beth Nielsen, Subtle, Pervasive, Harmful: Racist and Sexist Remarks in Public as Hate Speech, 58 J. Soc. ISSUES 265 (2002), which uses field observations and interviews to document the reactions of those who are targets of racist and sexist remarks. The problem, though, is that Tsesis considers it beyond dispute that "aggressive ideology" necessarily results in an "[in]accurate depiction of its subjects," and it is of course just that point that the First Amendment leaves for the citizenry to debate. I return to this theme below. See infra text accompanying notes 133-34.

95. See supra note 63 and accompanying text (noting that Imperial and Weimar Germany had hate-propaganda prohibitions).

96. See supra note 72 and accompanying text. 
prohibitions, ${ }^{97}$ but also because they are far better targets of government intervention.

This leads me back to a point I raised at the end of the previous Section about Tsesis's reliance on historical examples to support his view that "hate speech" should be criminalized: a different methodology would have more effectively uncovered the relevant facts. Tsesis bases his argument on carefully chosen historical examples that are designed to elicit outrage, but he does so without any comparative analysis at all. To make credible assertions about the role racist ideology plays in various historical examples, it is not enough simply to make a deterministic causal claim that expressions of racist ideology were "necessary" for the persecution to take place. Rather, one must do comparative socio-historical analysis and ask whether there is a causal connection in the probabilistic sense. While a comprehensive international comparative study might be too difficult, a comparative case study would not be, and this approach could be quite enlightening.

So let us return to the question of the Holocaust, Tsesis's first example in his argument for a ban on biased speech. Tsesis claims that anti-Semitic ideology developing slowly over centuries led to the Holocaust. While he gives lip service to the role that social and economic conditions played, ${ }^{98}$ the crux of his point is that the expression of antiSemitic views, during but particularly before the Nazi era, was part of what allowed the Holocaust to happen. To show causation in the relevant sense, however, one needs at least one example of a historical situation in which social and economic conditions were comparable with Weimar Germany, and yet there was no misethnic ideology. Or if we ask the question the other way around, why was it in Germany rather than in any number of other European countries that the Nazis came to power? Was the level of anti-Semitic messages higher in Germany? Many historians argue that the answer is "no," " which suggests that there may not even be a correlative

97. Cf. Gates, supra note 21 , at 57 ("Alas, even if hate did disappear, aggregative patterns of segregation and segmentation in housing and employment would not. Conversely, in the absence of this material and economic gap, no one would much care about racist speech." (emphasis added)).

98. TsESIS, supra note 5, at 110.

99. See, e.g., Wistrich, supra note 48:

[I]n any ranking of anti-Semitism in the pre-1914 era, Germany must be put some distance behind not only Austria but several other European countries. Since its unification in 1870, Germany had experienced nothing comparable to the antiSemitic paroxysm during the Dreyfus Affair in France, Lueger's electoral triumphs in Vienna, the systematic persecution of Jews in Romania, or the 
connection let alone a causal one in the relevant, probabilistic sense. Without asking a comparative question, one simply does not know whether every society, when faced with the economic and social conditions of Weimar Germany, would necessarily have responded with some sort of discriminatory oppression (whether based on race or ethnicity or any number of other grounds), irrespective of what happened in the immediately preceding nine centuries in that country. ${ }^{100}$ If this is true (and Tsesis gives us no information one way or the other to answer this question), then how could a ban on biased speech help even to reduce the probability of future calamities such as the Holocaust?

Tsesis does discuss the social psychology of scapegoating, ${ }^{101}$ but none of this discussion explains the important question: Why did the Holocaust happen when it did and where it did? His theory of social scapegoating, premised as it is on human psychology, does nothing to help us understand why, for example, the Holocaust did not occur in France at the time of the Dreyfus affair. ${ }^{102}$ Or for that matter, given Tsesis's indictment of Luther as partly responsible for the Holocaust, ${ }^{103}$ why it did not happen in German-speaking lands in the late sixteenth century.

His claims about American slavery suffer from the same methodological flaw. As I have noted above, historians hotly contest Tsesis's claim that racism led to slavery. Even accepting Tsesis's view of history, however, the relevant causal question can be answered only by looking at things comparatively. For example, why was there slavery in

devastating pogroms in czarist Russia, then universally seen as the greatest persecutor of the Jews.

$I d$. at 29 .

100. I note that in his historical examples Tsesis focuses entirely on the national level. What is interesting is that while he views the United States as a "hate speech haven" in the Internet era, he completely ignores the fact that ideas, whether racist or otherwise, have always crossed international borders. Surely French anti-Semites in the 1930s had just as much access to the expression of anti-Semitic ideologies as did the Germans. And if he wants to indict Luther for the Holocaust because Nazis "periodically invoked Luther's teachings to justify passing anti-Semitic laws and racial policies," then presumably the Danes, whose state church has been Lutheran since 1536, are more connected ideologically to Luther than was the Austrian Hitler who grew up in the Catholic Church. TsEsIS, supra note 5 , at 12 . See also supra note 46.

101. Id. at 85-98.

102. In the $1890 \mathrm{~s}$, the French Intelligence Service determined that a spy had passed secret military documents to the Germans. Captain Alfred Dreyfus, a wealthy Jew from Alsace, was wrongly accused of being the spy. After learning of the accusation, the publisher of one of the many anti-Semitic papers in France began a vitriolic campaign against the Jewish officer, and in a wave of anti-Semitic fervor, Dreyfus was convicted of high treason after a farcical trial based on the flimsiest of evidence. See generally ERIC CAHM, The Dreyfus AFFAIR In French SOCIETY AND Politics (1996).

103. See supra note 46 (citing TSESIS, supra note 5 , at 25). 
British North America, but not in Britain? Were expressions of racist ideology stronger in the colonies? Were they nonexistent in the mother country? These strike me as the type of questions one needs to ask if one's goal is to understand the role "hate speech" plays in "pav[ing] the way for harmful social movements" (as the subtitle of Tsesis's book puts it).

In sum, Tsesis's methodology fails to ask the one question we need to know before we even begin to address the merits of his proposed statute: Is there a causal relationship, in the probabilistic sense, between biased speech and any subsequent harm? Moreover, because his only claim is that biased speech was a logical cause of - that is, a necessary condition forthe oppression he describes, the relevant corollary of that claim is the following: If a society could completely eliminate all biased speech, it would thereby necessarily prevent a future Holocaust. Even accepting his premise at face value, then, he has not made any showing that a reduction in biased speech will decrease the likelihood or probability of a future Holocaust (or will reduce the incidence of individual bias crimes), because he has not asked the relevant question.

\section{CRiminal LaW AS A SOLUTION TO THE LONG-TERm HaRm CAUSED BY BIASED SPEECH}

Thus far, my critique has evinced a certain skepticism to Tsesis's premise, but I have studiously avoided taking his criticism of Brandenburg head on. In this Part, then, we shall assume that Tsesis's history is flawless and his deterministic causal claim is sufficiently supported. Let us even assume, therefore, the corollary of that causal claim: If a society could in fact suppress the relevant ${ }^{104}$ misethnic speech today, we would eliminate the possibility of a future calamity such as the Holocaust. ${ }^{105}$ Tsesis likely would respond: "Surely then, we should do so." Perhaps, but even with this assumption, Tsesis's conclusion runs into difficulties in the American context, difficulties for which he has failed sufficiently to account. In particular, the implications of his argument-that the United States should abandon Brandenburg for a rule that permits government to justify the suppression of speech on the basis of any causal connection to violence

104. By this, I mean that I assume further that we could precisely delineate which misethnic speech leads to the actions we wish to avoid. See supra Part II.

105. Recall that, since he is making a deterministic causal claim (biased speech is a necessary condition to a future Holocaust) rather than a probabilistic causal claim (biased speech increases the probability of a future Holocaust), the corollary is that his proposal will completely eliminate the possibility of a future Holocaust, not that it will simply reduce the possibility of one.

Note that I am focused here simply on the logic of Tsesis's argument. We need not assume, therefore, that his proposed statute will in fact suppress all of the relevant biased speech. 
orharm, no matter how remote ${ }^{106}$ - go far beyond biased speech and raise First Amendment problems that cannot be overcome by a simple appeal to the horrendous harm the speech causes. ${ }^{107}$

I put the point in terms of the First Amendment, since doctrinally that is where Tsesis's thesis runs into trouble, but my approach might be likened to what environmental policymakers call "comparative risk analysis" $" 108$ a comparison of the benefits of that proposal, discounted by the probability that it will in fact prevent the harms at which it is aimed, with the risks that adopting the proposal would entail.

Before I address what I view as some of the risks of Tsesis's proposal, however, let me point out a few things: First, even though I will assume for now that he has made a claim of deterministic or logical causation, I want to emphasize that I consider the probability of an event like the Holocaust or a reinstitution of slavery to be extremely low in the present-day United States, even without the adoption of a ban on biased speech. ${ }^{109}$ Biased speech may be a necessary condition for such harm, but it is obviously not a sufficient one. Therefore, while I am assuming at the moment that a complete elimination of biased speech would necessarily prevent a future Holocaust from happening, I am not assuming that such an event would happen in the absence of a complete ban on biased speech.

Second, it is important to view Tsesis's desire to abandon Brandenburg in light of the fact that the First Amendment currently permits the imposition of various forms of liability for expressions of racist ideology. ${ }^{110}$ Title VII race discrimination suits, ${ }^{111}$ criminal liability for

106. Recall that Tsesis's connection includes speech that occurs centuries before the harm. See supra note 46.

107. Let me be clear that I am not arguing that Brandenburg is defensible in all its particulars. As Kent Greenawalt has pointed out, the implications of the Court's language are not obvious and potentially are troubling if taken literally. See Kent Greenawalt, Speech and Crime, 1980 Am. B. Found. RES. J. 645, 650-53 [hereinafter Greenawalt, Speech and Crime]. My focus is solely on Tsesis's claim that government should be able to use the possibility of long-term harm as a rationale for suppressing speech. Moreover, as I noted in Part II, Tsesis might be aiming at an extremely broad swath of speech. So, there may be a number of First Amendment doctrines that Tsesis's proposal would have to overcome. Here, I focus solely on Brandenburg because Tsesis's statutory proposal criminalizes incitement to discriminate and would thus clearly be unconstitutional under Brandenburg.

108. See generally Colloquy, Risk in the Republic: Comparative Risk Analysis and Public Policy, 8 Duke ENVTL. L. \& POL'Y F. 1 (1997).

109. See supra text accompanying note 81 .

110. See generally WeInStEIn, supra note 11, at 61-65.

111. See, e.g., Delph v. Dr. Pepper Bottling Co. of Paragould, Inc., 130 F.3d 349 (8th Cir. 1997) (holding that persistent use of racist epithets by employer when referring to black employee violates Title VII). 
racist-inspired threats, ${ }^{112}$ and penalty enhancements for hate crimes ${ }^{113}$ are all examples of ways in which the law, in effect, penalizes individuals for the expression of racist views. Presumably, Tsesis would agree that biased speech in these circumstances also contributes to an increased likelihood of an atrocity such as the Holocaust. Therefore, to the extent that one accepts Tsesis's view about the long-term harm caused by biased speech, the benefits to be gained from Tsesis's proposal must be limited to the speech that it would suppress beyond that which is already proscribable under current doctrine. ${ }^{14}$ To the extent that speech already proscribable also contributes to the long-term harm Tsesis chronicles, he cannot use such speech in the balance sheet of harm even if his statute presumably would cover many of those circumstances.

\section{A. Brandenburg, Biased Speech, and Government Power}

Tsesis's thesis that the law should consider the long-term harm of speech is a direct attack on Brandenburg. Therefore, let us examine that case. Brandenburg involved the prosecution of a $\mathrm{Ku}$ Klux Klan leader under a "criminal syndicalism" statute, one that prohibited the advocacy of "crime, sabotage, violence, or unlawful methods of terrorism as a means of accomplishing industrial or political reform." 115 The defendant, Clarence Brandenburg, had organized a "rally" with twelve Klansmen at which he had made comments such as "Send the Jews back to Israel" and "Bury the niggers," slogans that were then followed by a claim that, "We're not a revengent organization, but if our President, our Congress, our Supreme Court, continues to suppress the white, Caucasian race, it's possible that there might have to be some revengeance taken. We are marching on Congress July the Fourth, four hundred thousand strong." ${ }^{116}$ No one was at the "rally" other than the twelve Klansmen along with a reporter and a cameraman, both of whom Brandenburg had invited to film the event. He was found guilty of criminal syndicalism and the Ohio Supreme Court upheld his conviction.

112. See, e.g., United States v. Khorrami, 895 F.2d 1186, 1193 (7th Cir. 1990) (upholding conviction for making threats when defendant repeatedly made anti-Semitic phone calls to a Jewish organization and sending the organization letters calling for the deaths of Israeli leaders). But cf. Black v. Commonwealth, 553 S.E.2d 738 (Va. 2001) (reversing convictions under cross-burning statute notwithstanding allegations that the cross-burning constituted a threat), cert. granted, 122 S.Ct. 2288 (2002).

113. See, e.g., Wisconsin v. Mitchell, 508 U.S. 476 (1993).

114. The costs would likewise be so limited. But, as we will see, the costs are directly related to the speech he would proscribe that is currently protected by the First Amendment.

115. Brandenburg v. Ohio, 395 U.S. 444, 445 (1969) (quoting OHIO Rev. Code ANN. $\S 2923.13)$.

116. Id. at 446, n.1. 
The U.S. Supreme Court reversed the conviction and invalidated the statute. In so doing, the Court fashioned what is now viewed as the modern-day "clear and present danger" principle: The First Amendment forbids the government from proscribing "advocacy of the use of force or of law violation except where such advocacy is directed to inciting or producing imminent lawless action and is likely to incite or produce such action." 117 In short, a speaker who advocates destructive action by others must intend that her statements produce imminent action and there must be a strong likelihood that the action will occur. Any looser connection between speech and subsequent action is treated as advocacy protected by the First Amendment.

Now consider Tsesis's assessment of the case. He states that Brandenburg "is based on the false assumption that the advocacy of future violence cannot have devastating effects." "118 This is a narrow and unpersuasive understanding of the case, ${ }^{119}$ raising two issues: First, he fails to understand that the logic of his argument goes far beyond racist speech. Second, he fails to understand that the theory that government must show a likelihood of imminent harm before suppressing speech that can cause harmful action does not deny that speech can have "devastating effects" over the long term. Rather, it is built largely on the view that the dangers of allowing government to criminalize such speech are greater. In fact, one need look no further than the judicial response to an arguably analogous type of speech, pornography, to see these two points clearly articulated.

117. Id. at 447.

118. TSESIS, supra note 5, at 137 (citation omitted). See also id. at 139 ("It is unduly facile to discount all but the most imminently dangerous calls to repressive actions as benign."); id. at 193 (“[T]he United States has maintained a head-in-the-sand approach to historical realities by refusing to acknowledge that any but the most immediate dangers can result from words targeting identifiable outgroups.").

119. In the text, I address what I view as Tsesis's misunderstanding of the real reasons for the rule in Brandenburg, but it strikes me as implausible, from the standpoint of a legal realist, to claim that the Brandenburg Court ignored empirical evidence about the long-term harm of racist ideologies. Tsesis says the Brandenburg "Court failed to evaluate whether there were historical reasons to think that a Ku Klux Klan rally might spark racist conflict." TSESIS, supra note 5, at 126 . Such a claim simply ignores the historical context of the case. The 1969 Brandenburg Court, which included Chief Justice Warren, Justices Douglas, Black, Brennan, Fortas (who heard argument but resigned prior to issuance of the opinion), and, perhaps most importantly for these purposes, Thurgood Marshall, was probably more sympathetic to the rights of "historically oppressed groups" than any other Supreme Court in the history of the nation. While the Court did not explicitly "evaluate" Tsesis's historical evidence, it was surely well aware of the "historical reasons to think a Ku Klux Klan rally might spark racist conflict" and it was notwithstanding this history, not because the Court ignored it, that the test was articulated as it was. Indeed, given the facts of the case, it is pretty clear, as Kent Greenawalt has pointed out, that the test in Brandenburg was "unnecessary to [the] decision." Greenawalt, Speech and Crime, supra note 107, at 650. 
Proponents of a ban on pornography have long argued that there is a direct causal connection between pornography and harm to women. ${ }^{120}$ The City of Indianapolis promulgated a ban on pornography justified on precisely this ground. When the ordinance was challenged in American Booksellers' Association v. Hudnut, ${ }^{121}$ the Seventh Circuit invalidated the law but took great pains to make clear that it fully accepted the premise that pornography caused long-term harm to women.

Indeed, the Hudnut court's articulation of the harm that speech can cause reads like a page out of Tsesis's book, in both structure and tone. In language that Tsesis would, I am sure, gladly adopt as his own, the Hudnut court noted that "[a] belief may be pernicious-the beliefs of Nazis led to the death of millions, those of the Klan to the repression of millions. A pernicious belief may prevail." 122 Explicitly accepting Tsesis's view that the "marketplace of ideas" will not always result in "truth" and effectively adopting Tsesis's theory of the social psychology of scapegoating, the court continued:

People taught from birth that black people are fit only for slavery rarely rebelled against that creed; beliefs coupled with the self-interest of the masters established a social structure that inflicted great harm while enduring for centuries. Words and images act at the level of the subconscious before they persuade at the level of the conscious. Even the truth has little chance unless a statement fits within the framework of beliefs that may never have been subjected to rational study.

Thus, the court had little difficulty accepting the causal connection between pornography and harm to women. ${ }^{124}$

Nonetheless, the court invalidated the ordinance. The court noted first that by itself the causal argument could not be limited to pornography, ${ }^{125}$

120. Catharine A. MacKinnon, Pornography, Civil Rights, and Speech, 20 HARV. C.R.C.L. L. Rev. 1, 46 (1985). See also Cass R. Sunstein, Democracy and the Problem of FREE SPEECH 217-18 (1993); Richard Delgado \& Jean Stefancic, Pornography and Harm to Women: “No Empirical Evidence?", 53 OHIO St. L.J. 1037 (1992); U.S. ATT'Y GEN's COMM'N ON PORNOGRAPHY, FINAL REPORT 299-351 (1986).

121. 771 F.2d 323 (7th Cir. 1985), summarily aff"d, 475 U.S. 1001, reh" $g$ denied, 475 U.S. 1132 (1986). A summary affirmance, in contrast to a denial of certiorari, is theoretically a decision on the merits.

122. Id. at 328 .

123. $I d$. at 329 .

124. Id. ("[W]e accept the premises of this legislation. Depictions of subordination tend to perpetuate subordination. The subordinate status of women in turn leads to affront and lower pay at work, insult and injury at home, battery and rape on the streets.").

125. Id.

If pornography is what pornography does, so is other speech. Hitler's orations affected how some Germans saw Jews. Communism is a world view, not simply a Manifesto by Marx and Engels or a set of speeches. Efforts to suppress communist speech in the United States were based on the belief that the public acceptability 
and second, that,

Most governments of the world act on this empirical [basis], suppressing critical speech. ... In the United States, however, ... the strength of the support for this belief is irrelevant. [citing, inter alia, Brandenburg . . . Racial bigotry, anti-semitism, violence on television, reporters' biases-these and many more influence the culture and shape our socialization. None is directly answerable by more speech, unless that speech too finds its place in the popular culture. Yet all is protected as speech, however insidious. Any other answer leaves the government in control of all the institutions of culture, the great censor, and director of which thoughts are good for us.

In effect, the court is assuming that racist speech causes long-term harm. The historical and psychological premises of Tsesis's bookwhether correct or not-simply confirm what many people, including at least one important court, ${ }^{127}$ already believe. Brandenburg is thus premised not on a failure to understand that speech can cause long-term harm but

of such ideas would increase the likelihood of totalitarian government. Religions affect socialization in the most pervasive way. ... Many people believe that the existence of television, apart from the content of specific programs, leads to intellectual laziness, to a penchant for violence, to many other ills. The Alien and Sedition Acts passed during the administration of John Adams rested on a sincerely held belief that disrespect for the government leads to social collapse Id. and revolution - a belief with support in the history of many nations.

126. Id. at 329-30 (emphasis added). Much of Tsesis's critique stems from his view that the First Amendment is built solely on a theory that the "marketplace of ideas" will result in "truth" in an objective sense. TSESIS, supra note 5, at 130-37. He sees Justice Oliver Wendell "Holmes's legal relativism and skepticism [as] the philosophical vertebrae of his 'marketplace of ideas' doctrine." Id. at 131. He also rejects Holmes's "Social Darwinist definition of "truth." Id. at 188. For these reasons, he claims the whole "marketplace of ideas" theory should be rejected. See id. at 137 ("The 'marketplace of ideas' doctrine is based on a relativistic social theory that has imbedded itself into American jurisprudence. Its premises support the powerful, even when their aspirations endanger democracy. Discrimination and intolerance should not be given the opportunity to win in the power market."). There is a wealth of scholarship on the broad issue of the role of Justice Holmes's philosophical views on his First Amendment jurisprudence. See generally G. Edward White, Justice Holmes and the Modernization of Free Speech Jurisprudence: The Human Dimension, 80 CAL. L. REV. 391, 393 nn.10, 12 (1992) (listing additional sources for reference); G. Edward White, Justice Oliver Wendell Holmes: LaW AND the InNer SELF 412-54 (1993). Since White's 1993 book, the commentary has continued. See, e.g., Vincent Blasi, Reading Holmes Through the Lens of Schauer: The Abrams Dissent, 72 Notre Dame L. Rev. 1343 (1997). To conclude, as Tsesis does, that we should accept the majority opinion in Gitlow, simply because Holmes was a relativist, is to ignore a huge debate about the many possible ways in which the "marketplace of ideas" should be viewed. As this passage in Hudnut demonstrates, one strand embedded in the imminent-harm requirement in Brandenburg makes Holmes's alleged deference to majoritarian will irrelevant. The Hudnut court makes clear that, though the "marketplace" may fail, allowing the government to dictate the truth has different risks.

127. See supra text accompanying notes 121-26 (discussing Hudnut, 771 F.2d 323). 
instead on the belief that there are "costs" to permitting speech suppression: Allowing government to suppress speech because of the potential for longterm harm can effectively amount to suppressing speech based on disagreement with the ideas. What animates the "imminent likelihood of harm" requirement, therefore, is the view that government has no place in defining the truth, not the view that truth will somehow always prevail. ${ }^{128}$ As viewed through the lens of Hudnut, then, Brandenburg can be seen as a prophylactic rule to prohibit government from using a long-term harm rationale to suppress speech based on the government's view of truth.

With Hudnut in mind, let us now look more closely at the two issues I raised regarding Tsesis's theory of Brandenburg: (1) a long-term harm rationale cannot be narrowly confined to racist ideologies; and (2) the costs of allowing government to dictate the truth to its citizenry must be more seriously taken into account, even if objective truth does not arise in the absence of government intervention and even if the regulated speech causes long-term harm.

First, Tsesis's book fails to explain why abandoning Brandenburg for racist ideologies based on a long-term harm rationale would not fundamentally increase a government's power to suppress all sorts of other speech based on similar grounds. ${ }^{129}$ If Tsesis's argument is correct that by

128. I do not mean to imply that the classic "marketplace of ideas" view that objective truth will prevail has been rejected in all circumstances. I am simply claiming that it is not what is really animating the Brandenburg rule.

129. C $f$. Greenawalt, Fighting Words, supra note 90, at 63 (while considering the question "close," noting that one of the problems with arguments based on long-term harm is the "difficulty in seeing how the line of permissible restriction is to be drawn once the harm of messages becomes the main basis for suppression"). Tsesis does claim, at times, that fundamental values of equality embedded in the Equal Protection Clause, or "indispensable ethical value in a representative democracy," might justify special treatment for racist speech. TSESIS, supra note 5, at 142, 162. See also id. at 174 ("[H]ate speech . . is incompatible with democracy."). There is, of course, a huge volume of literature on the relationship between the principles of equality and freedom of expression generally and between the Fourteenth Amendment's Equal Protection Clause and the First Amendment's Free Speech Clause more specifically. Compare, e.g., Akhil Reed Amar, The Case of the Missing Amendments: R.A.V. v. City of St. Paul, 106 HARV. L. REV. 124 (1992); STEVEN H. Shiffrin, Dissent, InJUstice, AND THE MEANings OF AMERICA 78-79, n.184 (1999) with, e.g., Post, supra note 11, at 314-17. See also Kenneth L. Karst, Boundaries and Reasons: Freedom of Expression and the Subordination of Groups, 1990 U. ILL. L. REV. 95. Moreover, while much of this literature also includes the claim that racist speech differs from other types of speech because racist speech undermines fundamental values, the same claim could certainly be made about flag burning. See Texas v. Johnson, 491 U.S. 397, 421, 429 (1989) (Rehnquist, J., dissenting) ("The American flag ... has come to be the visible symbol embodying our Nation.... [It] is not simply another 'idea' or 'point of view' competing for recognition in the marketplace of ideas."). See generally Post, supra note 11, at 315-16. In any event, this argument is precisely the line of reasoning upon which those who have sought to ban speech have always relied. See, e.g., Mark A. Graber, Old Wine in 
itself, any causal connection between speech and harm, no matter how remote, is sufficient to permit the government to suppress speech, then all the advocacy/incitement cases the Court decided before Brandenburg were correctly decided and the Alien and Sedition Acts would be constitutional. ${ }^{130}$ Teaching Marxism could be proscribed, ${ }^{131}$ and the government could jail those who oppose a war the government supports. ${ }^{132}$ Ultimately, giving government the power to suppress speech on as loose a causal connection as Tsesis suggests-to give government the power to

New Bottles: The Constitutional Status of Unconstitutional Speech, 48 VAND. L. REV. 349, 366-72 (1995) (noting that "in every age the leading proponents of various bans on certain ideas have insisted that the First Amendment does not fully protect the right to deny or criticize what their generation regards to be fundamental constitutional values"). As a question of doctrine, moreover, "courts have consistently held that within public discourse the antidiscrimination norm of equality should be subordinated to the value of democratic autonomy." Robert C. Post, Sexual Harassment and the First Amendment, in DiRECTIONS IN Sexual Harassment Law (Catharine A. MacKinnon \& Reva B. Siegel eds., forthcoming 2003). See also GREENAWALT, Fighting WorDS, supra note 90, at 61 ("[T] he courts have not been receptive to the notion that the Fourteenth Amendment authorizes restriction of speech that would otherwise fall within a protected category."). In any event, suffice it to say that Tsesis adds nothing original to these debates. Moreover, because of the breadth of speech that Tsesis would criminalize, the balance in the debate would shift markedly in favor of freedom of expression and even many of those who have argued for limitations on expression based on an equality rationale would not be willing to accept his broad proposed statute. For purposes of this Review, however, I need not enter this debate since Tsesis's thesis focuses on the long-term harm caused by the speech.

130. Cf. N.Y. Times Co. v. Sullivan, 376 U.S. 254, 276 (1964) (noting that it is now commonly believed that the Alien and Sedition Acts were unconstitutional).

131. Dennis v. United States, 341 U.S. 494 (1951). One point of note: Tsesis may well be consistent here. He appears to view Gitlow v. New York, 268 U.S. 652 (1925), as rightly decided. Tsesis approvingly quotes the Gitlow majority:

It cannot be said that the State is acting arbitrarily or unreasonably when, in the exercise of its judgment as to the measures necessary to protect the public peace and safety, it seeks to extinguish the spark without waiting until it has enkindled the flame or blazed into the conflagration.

TSESIS, supra note 5, at 139; see also id. at 124 ("The Gitlow majority... clearly recognized the potentially long-term inflammatory effects of speech and understood the dangers of not immediately curbing instigative words."). Gitlow involved a prosecution of a "member of the Left-Wing Section of the Socialist Party" solely for printing and distributing the "Left Wing Manifesto." Gitlow, 268 U.S. at 655. The conviction was upheld notwithstanding the fact that "[t]here was no evidence of any effect resulting from the publication and circulation of the Manifesto." Gitlow, 268 U.S. at 656. If Tsesis does regard Gitlow as rightly decided and would take his argument to its logical conclusion, he is at least consistent and has not fallen victim to what Robert Post has called "the fallacy of immaculate isolation"- that is, the idea that one can characterize the impact of banning particular speech as de minimis and consider the harm to First Amendment values minimal. See Post, supra note 11, at 315-16. Of course, this would mean instead that Tsesis is willing to effectively rewrite modern First Amendment doctrine for all sorts of speech.

132. Frohwerk v. United States, 249 U.S. 204 (1919); Debs v. United States, 249 U.S. 211 (1919). See also Hess v. Indiana, 414 U.S. 105 (1973). 
censor Luther to prevent Hitler-is little different from giving government the power to declare certain ideas to be wrong.

As I noted above, this may be Tsesis's ultimate goal-to have government declare that any expression of racial and ethnic inequality is simply a "false characterization[]." "133 If so, then it is not difficult to see why courts in the United States would be reluctant to accept Tsesis's argument, even if his history were flawless. Once the question is whether government may suppress an idea simply because the idea is wrong, Tsesis's thesis runs into grave difficulties in the United States. As Justice Brennan put it, "[t]he First Amendment does not guarantee that... concepts virtually sacred to our Nation as a whole-such as the principle that discrimination on the basis of race is odious and destructive-will go unquestioned." 134

The second issue is far trickier and requires consideration of competing values: the potential long-term harm of speech and the potential harm of government censorship. Certainly, one can argue that the Hudnut court's approach of assuming the harm caused by pornography while ignoring it altogether in the constitutional calculus seems incomplete, even if it has a certain logical appeal. Indeed, as Frank Michelman has pointed out, Hudnut seems troublesome because the court effectively elevated the view that government censorship is bad to an irrebuttable precept, such that no countervailing harm can matter. ${ }^{135}$ If one could in fact suppress the relevant speech to prevent a future Holocaust and there were no other

133. TSESIS, supra note 5, at 200; see supra note 94 and text accompanying notes 92-94.

134. Texas v. Johnson, 491 U.S. 397, 418 (1989). In Johnson, the Court invalidated a flag-desecration statute. In a case about flag burning, Justice Brennan's dictum can only be seen as specifically aimed at those who argue for a ban on expressions of racist ideology. See WeInSteIn, supra note 11, at 121 (referring to this specific quotation and noting that "Brennan seemed to go out of his way to make sure that no one could mistake his position on the constitutionality of hate speech regulation"). Of course, this is hardly the only time the Court has articulated the view that preventing government suppression of ideas because of disagreement with those ideas is one of the foundations of the First Amendment. See, e.g., Police Dep't v. Mosley, 408 U.S. 92 (1972):

[A]bove all else, the First Amendment means that government has no power to restrict expression because of its message, its ideas, its subject matter, or its content. To permit the continued building of our politics and culture, and to assure self-fulfillment for each individual, our people are guaranteed the right to express any thought, free from government censorship. The essence of this forbidden censorship is content control. Any restriction on expressive activity because of its content would completely undercut the "profound national commitment to the principle that debate on public issues should be uninhibited, robust, and wideopen."

Id. at 95-96 (internal citations omitted) (quoting N.Y. Times Co. v. Sullivan, 376 U.S. 254, 270 (1964)).

135. Frank I. Michelman, Conceptions of Democracy in American Constitutional Argument: The Case of Pornography Regulation, 56 TENN. L. REV. 291 (1989). 
means of preventing such a calamity, it seems unsatisfying to respond with the Hudnut court's admonition about government as "the great censor." A little censorship does not sound all that bad if the only other option is the systematic slaughter of six million people.

Moreover, one can certainly disagree with the Hudnut court as to how much faith to place in government's ability wisely to exercise the power to proscribe speech that can cause long-term harm, and there is little doubt that Tsesis, like much of the rest of the world, ${ }^{136}$ implicitly does. It could be that the view that government cannot be trusted with the power to suppress speech based on either the potential for long-term harm or because certain ideas are themselves so reprehensible as to be fundamentally at odds with a democratic state is simply an ideological position grounded in an impressionistic assessment of history rather than in an empirical conclusion about the actual role of government in suppressing speech. Though I am inclined to disagree with that claim, I am not enough of an historian of censorship to know for sure.

But if Tsesis wants to convince Americans to abandon Brandenburg in favor of a regime that has the power to suppress biased speech, he needs to do more than say biased speech leads to long-term harm. He needs at least to acknowledge and address the fact that laws are enforced by government officials, human beings who can-and, throughout history, have-abused the power he wishes to confer upon them. ${ }^{137}$

In fact, what is perhaps most troubling about Tsesis's thesis is the inherent paradox of his claim that a criminal statute, one that would place prosecutorial discretion in a government official, would alleviate the harms he describes when each one of the historical examples he gives (the Holocaust, American slavery, and the expulsion of indigenous Americans from their land) involves oppression committed by governments. Others have discussed at length the fact that, rather than protecting those Tsesis refers to as "outgroups," regimes of hate-speech regulation ${ }^{138}$ have been disproportionately used to suppress the speech of such groups. ${ }^{139}$ For

136. Cf. Brugger, supra note 90, at 14 ("[U]nlike Germans, Americans do not trust government to select 'good' over 'bad' opinions-a consequence of this attitude is that viewpoint discrimination by representatives of the government, even if directed at 'evil speech,' is viewed with suspicion ....").

137. Even as unswerving a proponent of hate speech regulation as Mari Matsuda has explicitly acknowledged that her proposal (a narrower proposal aimed at face-to-face epithets) "goes against the long-standing and healthy American distrust of government power." Matsuda, supra note 11, at 2322.

138. Here I use "hate speech" in the more common sense of that phrase, but I doubt the point loses its force when applied to Tsesis's even broader definition.

139. See, e.g., Gates, supra note 21, at 43-46; Nadine Strossen, Regulating Racist Speech on Campus: A Modest Proposal?, 1990 DukE L.J. 484, 556-59. 
example, the first prosecution under Canada's anti-pornography law was against a homosexual bookstore, and "copies of a book widely assigned in women's studies courses, Black Looks: Race and Representation by the well-known black feminist scholar bell hooks, [were] confiscated by Canadian authorities as possible "hate literature." "140 The University of Michigan's campus "hate speech" code ${ }^{141}$ likewise produced an unenviable record for minorities: whites charged more than twenty blacks with racist speech; the two times that punishment was meted out for racist speech both involved black students; and the only student subjected to a full-fledged disciplinary hearing under the policy was a black student who claimed he was "singled out because of his race and his political views." 142 Of course, these are only examples, but however widespread problems of this sort might be, the criticism of "hate speech" laws on this basis becomes even stronger when viewed in light of Tsesis's thesis, that censoring racist ideologies is justified because expression of those views has historically led to government-sanctioned oppression like the Holocaust.

Interestingly enough, at one point Tsesis even argues that many contemporary politicians are connected with white supremacists. In particular, he criticizes several government officials, including Mississippi Governor Kirk Fordice and U.S. Attorney General John Ashcroft, for their relationship with the Council of Conservative Citizens, a group that espouses white separatist views. ${ }^{143}$ And yet it is these executive branch officials who, under Tsesis's proposal, would have the ultimate prosecutorial discretion to initiate charges. It is they who will decide, in the first instance, what constitutes a "historically persecuted group" (in the language of Tsesis's proposed statute) and what sort of actions are likely to "incit[e] others to discriminate, persecute, oppress, or commit any similar acts." ${ }^{144}$ If Tsesis believes they are racists, this fact alone should be enough to give him pause.

Indeed, one more example might best illustrate what strikes me as the paradox of Tsesis's thesis. Recall that one historical example Tsesis uses to support his argument for abandoning Brandenburg was the claim that expressions of racist ideology led to slavery. Of course, Brandenburg was not the law in the antebellum period, and so presumably, Tsesis's proposed statute outlawing biased speech could have been constitutional then, at least

140. See Gates, supra note 21 , at 43 .

141. See Doe v. Univ. of Mich., 721 F. Supp. 852 (E.D. Mich. 1989) (invalidating the code).

142. Strossen, supra note 139 , at 557-58 (citation omitted).

143. TSESIS, supra note 5 , at 76-77.

144. Id. at 207. 
without the constraint of an "imminent harm" requirement. But what did in fact happen in the absence of Brandenburg? During the 1830s, a slew of Southern legislatures passed laws aimed at suppressing abolitionist speech. Why? Because the abolitionists' ideas could bring about violence-that is, slave rebellions - and even threaten the survival of the Union. ${ }^{145}$ Using the standard of deterministic causation that Tsesis uses in the historical section of his book, history obviously proved them correct. The abolitionists' speech (slaveholders no doubt could have characterized it at the time as "hate speech") certainly "pave[d] the way" for slave rebellions and, of course, the Civil War. ${ }^{146}$ And yet, in a regime without some kind of imminent harm requirement such as to be found in Brandenburg (and without some form of First Amendment incorporation or a state constitutional provision similar to the First Amendment), those laws presumably would be constitutional.

\section{B. The Need for Precision in Drafting a Criminal Prohibition on Biased Speech}

Finally, let me return to Tsesis's proposed criminal statute because it is in the specific context of his actual proposal that we can begin to evaluate the worry that permitting a loose connection between speech and action amounts to allowing government to censor unpopular ideas.

As I noted earlier, Tsesis advocates giving government the power to imprison

(1) [a]nyone inciting others to discriminate, persecute, oppress, or commit any similar acts against members of a historically persecuted group; ${ }^{147}$ (2) where it is substantially probable or reasonably

145. "[B]y 1835 the assumption that abolitionist publications would lead to slave rebellions seemed so obvious to many Northerners and Southerners that it needed no demonstration." Michael Kent Curtis, The Curious History of Attempts to Suppress Antislavery Speech, Press, and Petition in 1835-37, 89 Nw. U. L. Rev. 785, 802 (1995).

146. See generally id. at 802-04. There are, of course, normative reasons why we might want to "blame" racist speech, rather than abolitionist speech, for the Civil War. My point is simply that a long-term harm rationale permits government to suppress both "good" and "bad" speech.

147. One thing to note about this language is that the statute does not even require that the "discrimination," "persecution," etc. be based on race or ethnicity; it merely requires that the discrimination be against a member of a historically persecuted group, and thus all that is necessary is that the potential victim of the incitement be a member of a historically persecuted group. If read literally then, Tsesis's incitement standard (putting aside for a moment the third prong of the statute - the "intent ... to promote destructive behavior" language) would apply to any situation in which a member of a historically persecuted group is in the category of those being discriminated against, irrespective of whether the categorization was based on race or ethnicity. Advocacy for lower bus fares for children could thus be covered by his incitement standard simply because some adults are black. That the categorization is based on age is irrelevant as long as a member of a "historically 
foreseeable, based on the content and context of the message, that its dissemination will elicit such acts; and (3) where the speaker intended the message to promote destructive behavior.

He then provides for an affirmative defense if "the statement was uttered as an expression of opinion on a neutral scientific, academic, or religious subject and/or the statement was made to eliminate the incidence of hatred toward a historically persecuted group." 149

I would like to focus on a few aspects of the statute's language. First, notice that the proposed statute prohibits "incit[ement] . . to discriminate." As I explain presently, this language is extremely broad. Second, notice the language requiring that the speaker intend "to promote destructive behavior." This is problematic for a couple of reasons I discuss below. Third, notice that there is no defense for expressions of opinion on matters of policy. I am not sure whether this is intentional, but given that a large amount of the speech Tsesis describes in the first half of the book involves policy debates, it may well be. This likewise is a significant problem.

If we look at a few hypotheticals, we can see the problems that could arise. In 1990, there was a controversy about whether Shoal Creek Golf Club, home of that year's Professional Golf Association ("PGA") Championships, would admit blacks. The question arose because the club, like most golf clubs that host PGA tour events, is private and thus claimed, under principles of the constitutional right of association, the right to exclude anyone it wanted on any basis whatsoever, including on the basis of race. When the PGA changed its rules to require clubs that hosted PGA tour events to integrate, many of the segregated clubs changed their rules while others continued their discriminatory policies and simply stopped hosting tournaments. ${ }^{150}$ Or consider another example: As is well known in the wake of the "don't-ask, don't-tell" controversy, the Department of Defense excludes homosexuals from military service. ${ }^{151}$ Both the segregated golf club and the military have policies that could easily be characterized as "discriminat[ory]" towards "members of a historically persecuted group," discrimination are sanctioned by positive law in the United States.

persecuted group" is somehow being discriminated against. This is probably just a drafting error, which presumably could be fixed by adding language to the effect of "because of their status as members of a historically persecuted group" to the end of the first prong of the proposed statute.

148. TSESIS, supra note 5, at 207.

149. Id.

150. Jaime Diaz, In Golf, Integration Is More Than 9-Iron Away, N.Y. TIMES, Aug. 5, 1991, at C1.

151. See 10 U.S.C. $\S 654(b)$ (2000).

152. See supra text accompanying note 148 (quoting TsESIS, supra note 5, at 207). 
Consider someone who is one step removed from the policy. Rather than actually implementing one of these perfectly legal policies, this person simply advocates in favor of the golf club or the military policy by writing an op-ed piece or giving a public speech. Let us assume also that she does so convincingly enough to persuade those with the power to do so to maintain the discriminatory policy. This sort of advocacy would constitute (1) inciting others to discriminate (2) where it is likely that the statements "will elicit [the discriminatory] acts."

The only difficult issue appears to be whether implementation of the underlying discriminatory policies constitutes "destructive behavior" that the speaker "intends to promote." As I noted earlier, ${ }^{153}$ there is no definition of the phrase "destructive behavior," which by itself raises vagueness problems. Is "destructive behavior" the same as "discriminate, persecute, oppress, or commit any similar acts"? Is it a subset? Or are these two completely distinct categories? If "destructive behavior" is not simply a shorthand way of saying "discriminate, persecute, oppress, or commit any similar acts," this is a somewhat odd statutory requirement because there would be a mismatch between the first prong of the statute- the actual acts the defendant must incite in order to be found guilty-and the third prong - what the defendant must intend. Be that as it may, let us assume that the phrase "destructive behavior" is meant to be something different from "discriminate, persecute, oppress, or commit any similar acts." Even if we make this assumption, however, the phrase might still permit a broad application of the statute. Note, for example, that one meaning of the word "destroy" is to "ruin (someone) emotionally or spiritually." ${ }^{154}$ Without any further definitional clarity, it is thus at least plausible to argue that involuntary discharge from the Navy is "destructive," since it results in the loss of one's livelihood and, for some members of the military, their very community. ${ }^{155}$ While it might be a closer question in the case of exclusion from a golf club, there is likely evidence that being segregated from important athletic and social opportunities destroys the psyche of those being excluded-that is, the segregation of golf clubs "ruin[s] [those excluded] emotionally or spiritually." In short, Tsesis's proposal allows for the possibility that advocating in favor of one side of an important public debate could be viewed as illegal.

Admittedly, these examples stretch the meaning of the phrase "destructive behavior." This is presumably not what Tsesis had in mind, and one might be able to clarify this with more precise language. But,

153. See supra note 43.

154. THE New OXford AMERICAN DictionARy 464 (2001).

155. See Thomasson v. Perry, 80 F.3d 915 (4th Cir. 1996). 
consider another area of law where "discrimination" on the basis of race and ethnicity has been rampant throughout U.S. history: immigration policy. The Attorney General recently issued an order requiring adult male noncitizens over the age of sixteen who come from twenty-one different countries, primarily Arab and Muslim, to be interviewed, photographed, and fingerprinted. ${ }^{156}$ Let us take it one step further and imagine a proposal to revoke the immigration status of, and deport, every noncitizen from those countries. There is little doubt that such a policy would be discriminatory, and yet Congress might be able to pass such a law under its plenary powers over immigration; ${ }^{157}$ however, under Tsesis's proposal, advocating in favor of it might be criminalized since such advocacy would be "inciting others to discriminate" with the intent to "promote destructive behavior." I suspect this is likely to be much closer to what Tsesis means when he uses the phrase "destructive behavior." After all, one of the historical examples he gives is the expulsion of indigenous Americans from their land in the nineteenth century, and expulsion from the United States on the basis of one's national origin is at least somewhat analogous.

One response to all of these examples is that the word "discriminate" would cover only "illegal discrimination" so that one could advocate for "legal" discrimination. The term "incite" certainly retains connotations of abetting a crime. ${ }^{158}$ With the immigration example, one could perhaps argue that foreigners cannot be members of a "historically persecuted group," 159 or that Congress's powers over either the military or immigration are sui generis. But, it would be hard to square this sort of a

156. See John M. Broder and Susan Sachs, Facing Registry Deadline, Men From Muslim Nations Swamp Immigration Office, N.Y. TIMES, Dec. 17, 2002, at A16, available at http://www.nytimes.com/2002/12/17/politics/17IMMI.html. The countries are Afghanistan, Algeria, Armenia, Bahrain, Eritrea, Iran, Iraq, Lebanon, Libya, Morocco, North Korea, Oman, Pakistan, Qatar, Saudi Arabia, Somalia, Sudan, Syria, Tunisia, the United Arab Emirates, and Yemen. Id.

157. See Chae Chan Ping v. United States ("Chinese Exclusion Case"), 130 U.S. 581 (1889). Cf. Harisiades v. Shaughnessy, 342 U.S. 580 (1952); Reno v. American-Arab AntiDiscrimination Committee, 525 U.S. 471 (1999).

158. See Black's LAW Dictionary 765 (7th ed. 1999). Cf. Tsesis, supra note 5, at 203 (including among the considerations to be taken into account when regulating biased speech "[w]hether the [s]peaker [i]ntended the [d]eclarations to [i]ncite [c]riminal [a]cts against an [o]utgroup" (emphasis added)).

159. As Henry Louis Gates has explained, phrases such as "historically persecuted group" also are open to definitional problems. See Gates, supra note 21, at 33. Gates asked whether poor Appalachians are "historically oppressed" and then noted:

Once we had adopted the "historically oppressed" proviso, I suspect it would just be a matter of time before a group of black women in Chicago are arraigned for calling a policeman a "dumb Polack." Evidence that Poles are a historically Id. oppressed group in Chicago will be in plentiful supply. 
positivist spin on the word "discriminate" when the thrust of Tsesis's book is that advocacy in favor of slavery or the policy of native American dislocation should have been outlawed as "hate speech" notwithstanding the fact that the underlying discriminatory acts were clearly legal at the time. In any event, such a response would simply beg the question of what sort of "discrimination" should be legal, a question the First Amendment properly leaves the citizenry to debate without fear of prosecution.

In short, the practical problems of drafting a statute that avoids serious vagueness and overbreadth ${ }^{160}$ problems cannot be underestimated. It may be that Eleanor Holmes Norton was overstating it when she said, "It is technically impossible to write an anti-speech code that cannot be twisted against speech nobody means to bar." 161 But Tsesis's proposal does little to convince me that she was wrong.

\section{CONCLUSION}

In sum, although Tsesis's "goal of preventing atrocities against racial and ethnic minorities is laudable, he has not sufficiently supported his view that a criminal law banning what he refers to as "hate speech" would further that goal. Indeed, because he has not adequately considered the potential for government abuse that his proposal invites, his proposed law could very well do more harm than good.

In effect, what Tsesis's book depends on is hope, the hope that if a society declares "hate speech" to be illegal, it can eliminate "hate speech" and it can thereby eliminate hatred itself. One is led to presume this will end inequality based on differences of race, ethnicity, culture, and the like, and that genocide, institutionalized subjugation, and oppression will all vanish into thin air. One can only imagine what the world would be like if it were so simple.

160. Again, I use the term "overbreadth" in its lay, rather than doctrinal, sense.

161. Strossen, supra note 139, at 486. See also Michael W. McConnell, America's First "Hate Speech" Regulation, 9 Const. Comm. 17, 23 (1992) (while expressing tentative support for regulation of invective or epithets based on the rationale that such speech can silence its intended audience, noting that "we should also be aware that there are grave, and perhaps insuperable, difficulties in drafting regulations that are broad enough without being vague"). 